This is the final peer-reviewed accepted manuscript of

Antonellini, M.; Mollema, P. N.; DEL SOLE, LEONARDO: Application of analytical diffusion models to outcrop observations: Implications for mass transport by fluid flow through fractures. WATER RESOURCES

RESEARCH 53. ISSN 0043-1397

DOI: $10.1002 / 2016$ WR019864

The final published version is available online at: http://dx.doi.org/10.1002/2016WR019864

Rights / License:The terms and conditions for the reuse of this version of the manuscript are specified in the publishing policy. For all terms of use and more information see the publisher's website. 
Key Points:

- Validation of theoretical analytical fracture to matrix diffusion models with outcrop observations

- Joints and small faults are conductive to fluids and allow for mass transport by diffusion whereas veins have a barrier effect

- Integration of petrophysics, modeling, and redox front shapes is a tool for estimating transport and reaction time scales in fractured rocks

Correspondence to:

M. Antonellini,

m.antonellini@unibo.it

Citation:

Antonellini, M., P. N. Mollema, and L. Del Sole (2017), Application of analytical diffusion models to outcrop observations: Implications for mass transport by fluid flow through fractures, Water Resour. Res., 53, 5545 5566, doi:10.1002/2016WR019864.

\section{Application of analytical diffusion models to outcrop observations: Implications for mass transport by fluid flow through fractures}

\author{
M. Antonellini' ${ }^{1}$, P. N. Mollema1, and L. Del Sole ${ }^{1}$ \\ ${ }^{1}$ Department of Biological Geological and Environmental Sciences, University of Bologna, Bologna, Italy
}

\begin{abstract}
A pavement outcrop with excellent exposure of spatial relationships among joints, veins, small offset normal faults, and associated alteration halos (redox fronts) provided an opportunity to compare predictions of analytical models for reaction front propagation in a fracture-matrix system with a real-field situation. The results have important implications for fluid flow and pollutant transport through a fractured medium. The alteration halos observed suggest that all joints of different sets and most small faults are conductive to meteoric water at shallow depth. On the other hand, veins are local barriers to mass transport by diffusion. By using petrologic and petrophysical data, analytical modeling, and the width of the alteration halos, it was possible to estimate when the fracture network was open to fluid flow. The inferred time for fluid flow and diffusion through the fracture network is sensitive to the porosity $n$ of the rock matrix used in the analytical solutions: $2200 \pm 500$ years with $n 0.08,4600 \pm 900$ years with $n 0.05$, and 16,000 \pm 4000 with $n$ 0.02. The second and third age determinations are consistent with the landscape evolution of the area since the end of the last Würmian ice age and with the timing required to fill the fractures observed in outcrop. We suggest that analytical modeling is an important tool for the determination of transport and reaction time scales in fractured formations where it is constrained by a robust petrophysical and chemical properties data set.
\end{abstract}

\section{Introduction}

Alteration halos around fractures in rocks are often associated with preferential fluid flow through those fractures [Eichhubl et al., 2004, 2005, 2009]. When oxygenated water flows through a fracture and interacts with reduced sandstone matrix, a so-called redox front forms and propagates [Ortoleva et al., 1986]. A redox front separates oxidized rock (reddish-brown) from reduced rock (bluish-gray) [Miller et al., 1994]. In this paper, the oxidized rock around fractures is called the alteration halo and the outer edge of the alteration halo is defined as the redox diffusion front. In low-permeability rocks, the mass transport of dissolved oxygen from the fluid in the fracture to the matrix occurs mostly by diffusion, which supplies reactions in the rock matrix [Ortoleva et al., 1986; Sidborn and Neretnieks, 2007].

During the last three decades, the study of reactive transport in fractured rocks has attracted a large interest in the environmental and physical sciences, both in interdisciplinary theoretical and applied fields [Bryant et al., 2001]. In particular, research focused on transport in low-porosity rocks hosting nuclear waste repositories [Tang et al., 1981; Sudicky and Frind, 1982; Lever and Bradbury, 1985; Banwart et al., 1999; Smellie and Karls-son, 1999; Park et al., 2001; MacQuarrie and Mayer, 2005; Hölttä et al., 2008; Dideriksen et al., 2010; MacQuarrie et al., 2010; Hartley et al., 2015; Tsang et al., 2015]. Furthermore, redox front characteristics help to understand pollutant transport in porous [Cribbin et al., 2014] or fractured rocks [Akagawa et al., 2006]. The reaction chem-istry associated with redox fronts helps to constrain the dynamics of pollutants exchange from the high-permeability fracture to the surrounding low-permeability rock-matrix [Mutch et al., 1993; Mazurek et al., 1996; Rubin et al., 1997; Brown et al., 1998; Banwart et al., 1999; Molinero and Samper, 2006; Greer et al., 2010; Wu et al., 2010; Houseworth et al., 2013; Vujevic and Graf, 2015]. This is also of interest in the context of two-phase flow and DNAPL movement from fractures into the adjacent rock matrix [Esposito and Thomson, 1999].

Reactive transport of metal contaminants is also of concern in porous and fractured rocks, because of mining activities [Brown et al., 1998]. Redox front dynamics may help control mining-related pollution and guiding the exploitation of ore deposits [Marshall and Oliver, 2008]. Geochemical boundaries, such as those 
controlled by a change in redox conditions, were studied by a careful analysis of outcrops and the oxidation or reduction halos associated with fractures or other geologic features [Drake et al., 2009; Dideriksen et al., 2010]. Banwart et al. [1999] and Lee and Kim [2014] evaluated the recharge rates of hard rock fractured aquifers by studying alteration halo patterns.

The fundamental research questions that we address in this paper are: (1) Do outcrop characteristics of alteration halos associated with fractures match the predictions of theoretical diffusion models?; (2) Do alteration halos provide information on the connectivity and barrier properties of a fracture network in a low-porosity sandstone?; (3) Do alteration halos give quantitative information about flow and mass transport? The modeling performed in this study aims to constrain the time and spatial scales of the diffusionreaction processes based on the alteration halos observed in the outcrop. Such information is fundamental for assessing pollutant transport [Mutch et al., 1993] and rock slope stability in fractured and layered rocks [Meisina, 2006; Binet et al., 2007, 2009; Jomard et al., 2007; Bronnimann, 2011; Liu and Li, 2015; Galeandro et al., 2014; Szalai et al., 2014]. The novelty of our work is the integration of field observations, laboratory measurements, and analytical modeling to extract hydrologic information from alteration halos associated with fractures. We hope that the techniques that we present in this paper will be applied to fractures and halos in other geological settings.

In order to justify the analytical models used, we briefly review the available literature on the subject. Bryant and Thompson [2001] summarized theoretical, modeling, and experimental studies of reactive transport in porous media. These authors point out how the real behavior of geologic media is often different from theoretical predictions. The models differ from reality because of heterogeneity or where complex processes, such as matrix-fracture mass transfer, are occurring. During some reactive transport processes, the fractures and the porous medium undergo permeability and porosity modification [Sausse et al., 2001], due to precipitation and dissolution reactions [Chen and Liu, 2002].

The mass transfer and the form of redox fronts associated with diffusion and fluid flow in rock fractures was investigated by analytical modeling [Grisak and Pickens, 1980; Grisak et al., 1980; Tang et al., 1981; Sudicky and Frind, 1982; Rubin et al., 1997; Park et al., 2001; Wörman et al., 2003; Houseworth, 2006; Sidborn and Neretnieks, 2007, 2008; Houseworth et al., 2013; Rajaram and Arshadi, 2016], experimental work [Hölttä et al., 2008; Trivedi and Babadagli, 2009; Hatiboglu and Babadagli, 2010], and numerical modeling [Steefel et al., 2005; Spiessl et al., 2007; MacQuarrie et al., 2010; Vujevic and Graf, 2015; Watanabe and Kolditz, 2015]. Ortoleva et al. [1987a, 1987b] theoretically studied the physical processes associated with redox-infiltration fronts and their instabilities. Several processes control how dissolved oxygen (DO) in water drives redox reactions in the rock matrix; some of these processes are biotic (mediated by bacteria) and other abiotic [Sidborn and Neretnieks, 2007]. Shapiro [2001] and Molinero and Samper [2006] modeled reactive solute transport in fracture zones at the field scale in granite rock whereas Banwart et al. [1999] conducted borehole tests and geochemical monitoring to evaluate the hydrological and reactive processes during rapid recharge to fracture zones. Most work done so far focused on granite, metamorphic rocks [Shapiro, 2001], tuff [Reimus and Callahan, 2007], or shale [Willmann et al., 2013; Huang and Goltz, 2015], while this paper focuses on low-permeability sandstone. We refer to fracture as a general term defined by Priest and Hudson [1976, 1981] and Aydin [2000], which includes the following structures: veins, stylolites, joints, and faults. Faults are fractures with shear displacement (II or III mode), joints are opening mode I fractures [Pollard and Segall, 1987; Schultz and Fossen, 2008], and veins are opening mode I fractures filled with minerals.

\section{Methods}

\subsection{Study Area}

The outcrop that forms the basis for our analysis is located in the Northern Apennines (Emilia Romagna Region, Italy) at $44^{\circ} 10^{\prime} 5^{\prime \prime} \mathrm{N}$ latitude and $11^{\circ} 14^{\prime} 49^{\prime \prime} \mathrm{E}$ longitude, between the cities of Bologna and Florence at a topographic elevation of $1000 \mathrm{~m}$ (Figure 1). The exposure is in turbiditic sandstones of the Ligurian Monte Venere Fm (MOV). The structural geology of the Northern Apennines is complicated by multiple tectonic phases, changes in microplate movements, and different types of depositional environments, which lead to a fragmented and varied geology over short distances [Cibin et al., 2001; Antonellini and Mollema, 2002; Gasperi et al., 2005; Argnani et al., 2006]. At a regional scale, the turbiditic sandstone beds of the MOV Fm have an arkose to subarkose composition and are well cemented [Argnani et al., 2006]. The sandstone layers 


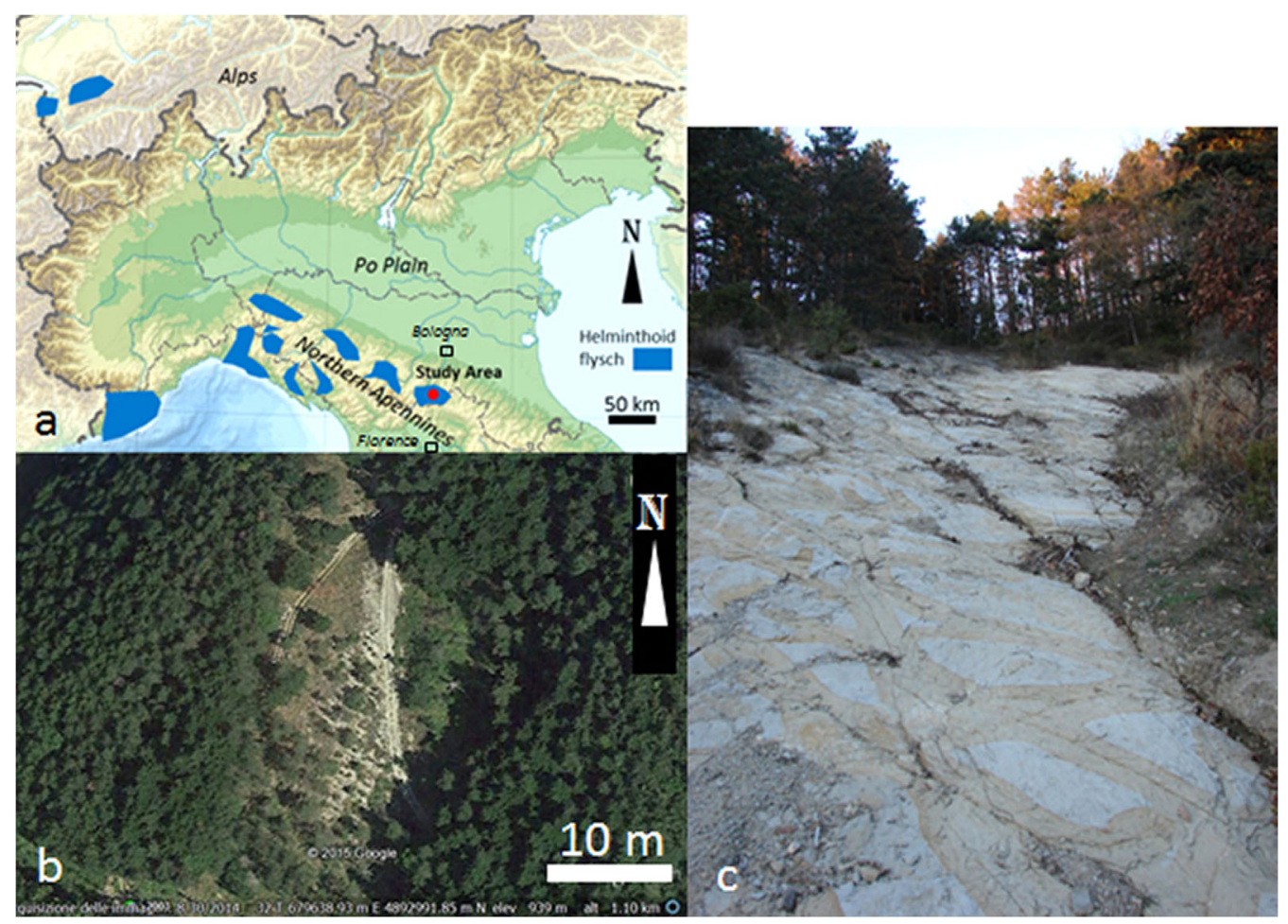

Figure 1. Index map. (a) Location of the outcrop (red dot) and of the Ligurian units (Helminthoid flysch blue color) in the Northern Apennines. The dashed line is the boundary of the Emilia Romagna region. (b) Aerial photograph of the outcrop. (c) Overview photograph of the outcrop that shows the alteration halos and their association with the fractures.

alternate with fine-grained marly deposits. The MOV Fm contains typical turbiditic flow structures such as wavy and cross-bed laminations and flute casts at the base of the turbidites. The strata are overturned in many places, including our study site. At the top of the MOV Fm, the siliciclastic fraction (clay) in the finegrained levels is prevalent over the calcareous fraction. The MOV Fm is one of the most landslide-prone turbiditic-sandstone sequences of the Northern Apennines (Italy) [Gasperi et al., 2005; Bordoni et al., 2007, 2010; Cervi et al., 2007; Leuratti et al., 2007; Ronchetti et al., 2008; Regione Emilia-Romagna, 2016].

\subsection{Modeling}

Given that the alteration halo boundaries observed in the field have all the characteristics of redox fronts propagating by diffusion [Sidborn and Neretnieks, 2007], we assume that they are as such and we study them with the analytical techniques used for reactive fronts by Sidborn and Neretnieks [2007] and Rajaram and Arshadi [2016]. In our case, the reactive front is the combination of a redox front where $\mathrm{O}_{2}$ in solution (hereinafter referred to as DO) diffuses into the rock matrix from water in the fracture and a dissolution front where $\mathrm{Fe}^{2+}$ goes into solution from the matrix (Figure 2a). Other assumptions of the analytical techniques are that flow is saturated and infiltration is continuous under a steady state regime. These assumptions are justified by the existence of a very thin soil zone (less than $0.2 \mathrm{~m}$; Figure 1c), the humid climate (especially during the last ice age) and the low rock porosity. During the fieldwork, we observed that saturated conditions persist for extended periods. This does not mean that the vadose zone is absent but in view of the lack of data for the application of unsaturated flow boundary conditions, we consider saturated flow a first approximation to the problem.

Following Sidborn and Neretnieks [2007], we assume that given the relative large size of individual bacteria $(0.5-5 \mu \mathrm{m})$, they mediate redox reactions only in the fracture (typical fracture opening $10 \mu \mathrm{m}$ ) and not in the porous matrix (pore throat sizes $<1 \mu \mathrm{m}$ ). We also assume that as atmospheric oxygen dissolved in rainwater infiltrates along the fracture, it is transported from the fracture by diffusion through the rock matrix and reaction with the $\mathrm{Fe}^{2+}$ in solution, so that the $\mathrm{DO}$ concentration will be different at different distances (depth from the surface in our case) along the fracture (Figure 2a). Among alternative reaction pathways in the porous matrix [Sidborn and Neretnieks, 2007], we consider nonoxidative dissolution of $\mathrm{Fe}^{2+}$ matrix 


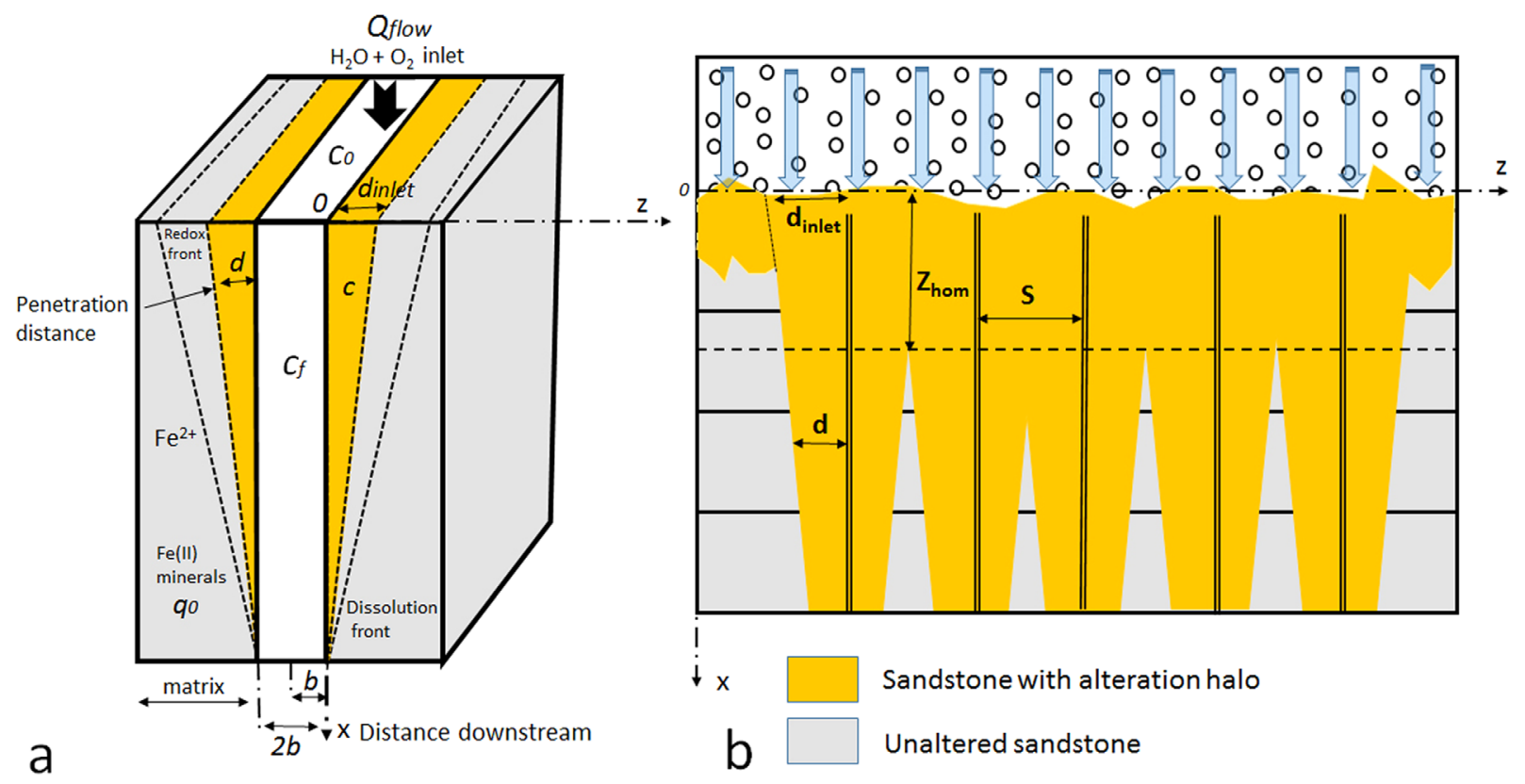

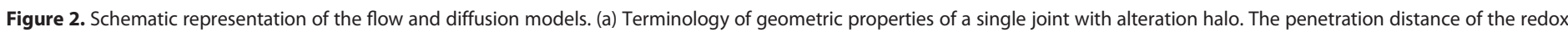
front is $d$ and $d_{\text {inlet }}$ is the penetration distance at the inlet of the fracture. The fracture opening is $2 b, c$ and $c_{f}$ are the DO concentrations in the pore water within the matrix and in the

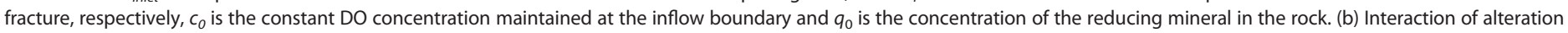

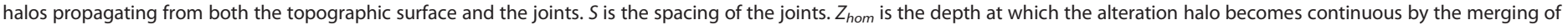
the alteration halos propagating from the joints.

minerals (biotite, chloritoid, and pyrite), diffusion of dissolved $\mathrm{Fe}^{2+}$ and $\mathrm{DO}$ in the matrix, and oxidation of the dissolved $\mathrm{Fe}^{2+}$ ions inside the rock matrix next to the fracture. This reaction path is based on the color of the sandstone (bluish-gray) that indicates reducing conditions ( $\mathrm{Fe}^{2+}$ dissolution) in the matrix far from the fracture, whereas close to the fracture the rock color (orange-brown) suggests oxidation of the dissolved $\mathrm{Fe}^{2+}$ (see also results of outcrop characterization).

We use analytical modeling to investigate (1) how DO within the fracture network affects the redox conditions in groundwater within the rock matrix surrounding the fractures; (2) how DO affects the position of the reactive front; and (3) whether field observations can be explained with model predictions.

\subsubsection{Reactive Front Position}

\subsubsection{Sidborn and Neretnieks [2007] Model}

The model presented by Sidborn and Neretnieks [2007] includes nonoxidative dissolution of $\mathrm{Fe}^{2+}$ matrix minerals, diffusion of dissolved $\mathrm{Fe}^{2+}$ and $\mathrm{DO}$ in the matrix, and oxidation of the dissolved $\mathrm{Fe}^{2+}$ ions inside the rock matrix. Additional simplifying assumptions (with respect to those listed in section 2.2) for this model are (1) the reaction with the mineral is instantaneous; (2) the DO concentration in the water filling the pores of the matrix is smaller than the reducing mineral concentration in the rock; (3) the reaction time is long enough to achieve quasi steady state conditions. These assumptions are reasonable in geologic conditions and time scales [Sidborn and Neretnieks, 2007]. In this case, the pseudo steady state approximation is valid [Neretnieks, 1986] and the two following mass-balance equations yield a solution for flow in the fracture and diffusion in the matrix:

$$
\begin{aligned}
\frac{\partial c_{f}}{\partial t}+v \frac{\partial c_{f}}{\partial x} & =\left.\frac{D_{e}}{b} \frac{\partial c}{\partial z}\right|_{z=0} \approx \frac{D_{e}}{b} \frac{\left.c\right|_{z=0}}{z} \text { (in fracture) } \\
\frac{\partial c}{\partial t} & =D_{p} \frac{\partial^{2} c}{\partial z^{2}} \quad R(c) \text { (in matrix), }
\end{aligned}
$$

where $c$ and $c_{f}$ are the DO concentrations in the pore water within the matrix and in the fracture, respectively, and $x$ and $z[\mathrm{~m}]$ are the directions along $(x)$ and normal to the fracture plane (z) (Figure 2a). $R$ is the depletion rate due to reaction; we assume it is infinitely large at the redox front. $b[\mathrm{~m}]$ is the half-aperture of the fracture, $D_{p}\left[\mathrm{~m}^{2} \mathrm{~s}^{1}\right]$ is the pore diffusivity, $D_{e}\left[\mathrm{~m}^{2} \mathrm{~s}^{1}\right]$ is the effective diffusivity in the matrix, and $v$ is 
the water flow velocity [m s ${ }^{1}$ ]. The effective diffusivity $D_{e}$ is related to the pore diffusivity $D_{p}$ and the diffusivity in the liquid $D_{o}$ by $D_{e} \quad D_{p} n \quad n\left(D_{0} / \tau\right)$ where $n$ is the porosity and $\tau$ the tortuosity [Sidborn and Neretnieks, 2007].

The initial and boundary conditions used to solve equations (1) and (2) are

$$
\begin{gathered}
c_{f}(t=0, x)=0, \\
c(t=0, x, z)=0, \\
c_{f}(t, x=0)=c_{0}, \\
c_{f}(t, x)=c(t, x, z=0),
\end{gathered}
$$

where $c_{0}$ is the constant DO concentration maintained at the inflow boundary.

A special case (for the previous assumptions) is where dispersion and diffusion in the fractures are neglected and the mass of the reducing mineral is much larger than the mass of DO. These latter conditions are those of a pseudo steady state [Sidborn and Neretnieks, 2007] and the first terms in equations (1) and (2) are equal to zero. When the reaction rate between DO and the reducing mineral is fast and approaching infinite, a sharp moving reaction front develops in the matrix. This assumption complies with the relative sharpness of the fronts observed in our field case. By using a simple mass balance equation that accounts for the amount of DO that diffuses into the matrix up to the reaction front and the amount of mineral that reacts, we can calculate the position of the redox front into the matrix $\left(d_{\text {inlet }}\right)$, after a time $t$ at the inlet of the fracture [Cooper and Lieberman, 1970]. At this position, the DO concentration is zero in the matrix

$$
d_{\text {inlet }}=d(t, \quad x=0)=\sqrt{2 \frac{D_{e} c_{0}}{q_{0} f} t} .
$$

The position $d$ to the reaction front at a location $x$ downstream is

$$
d(t, x)=\sqrt{2 \frac{D_{e} c_{0}}{q_{0} f} t} \quad \frac{D_{e} x}{v b}=\sqrt{2 \frac{D_{e} c_{0}}{q_{0} f} t} \frac{2 D_{e} x W}{Q_{\text {flow }}},
$$

where $f$ is the stoichiometric coefficient [mol Ox/mol Red], $q_{0}$ is the concentration of the mineral in the rock [mol Red $\left.\mathrm{m}^{3}\right], \mathrm{W}[\mathrm{m}]$ is the width of the fracture, and $Q_{\text {flow }}\left[\mathrm{m}^{3} \mathrm{~s}{ }^{1}\right]$ is the flow rate in the fracture. Equation (4) is valid for $d>0$; otherwise, it is equal to zero. Equations (3) and (4) are used to explore how far the reaction front penetrates into the matrix due to water flow along the fracture.

\subsubsection{Rajaram and Arshadi [2016] Model}

The model presented by Rajaram and Arshadi [2016] is based on a similarity solution for reaction front propagation in fracture-matrix systems. This solution neglects diffusion and dispersion in the fracture and assumes the existence of a sharp reaction front in the matrix. The solution applies to a broad variety of reactive transport problems where mineral reactions occur in fracture-matrix systems and is suitable for our study case (relative sharpness of the front observed in outcrop). By using, the terminology and reference system previously introduced (Figure 2a); the advective transport equations that Rajaram and Arshadi [2016] solve are the following:

$$
b \frac{\partial c_{f}}{\partial t}+\frac{Q_{\text {flow }}}{W} \frac{\partial c_{f}}{\partial x}=\left.2 n D_{p} \frac{\partial c}{\partial z}\right|_{z=0}(\text { in fracture })
$$

and

$$
\frac{\partial(n c)}{\partial t} \quad \frac{\partial}{\partial z}\left(n D_{p} \frac{\partial c}{\partial z}\right)=m k c M(\text { in matrix })
$$

where $n$ is the porosity (assumed $n \quad 1$ in the fracture), W $[\mathrm{m}]$ is the width of the fracture, $Q_{\text {flow }}\left[\mathrm{m}^{3} \mathrm{~s}{ }^{1}\right]$ is the flow rate in the fracture, $k$ is a mineral rate parameter with dimensions [mol ${ }^{1} L^{3} T^{1}$ ], $M$ is the mineral molar density [moles of mineral per unit porous medium volume], and $m$ is a stoichiometric coefficient $[m$ moles of $c$ reacts with $p$ moles of $M]$. The mineral mass balance equation is 


$$
\frac{\partial M}{\partial t}=p k c M
$$

The imposed initial and boundary conditions to solve equations (5)-(7) are the same reported in section 2.2.1.2 with the addition of condition

$$
M(t=0, x, z \geq 0)=q_{0}
$$

Rajaram and Arshadi [2016] invoke the presence of a sharp moving boundary reaction front $d(x, t)$, at which $c$ goes to 0 , and ahead of which the mineral is unreacted, to replace equation (6) with

$$
\frac{\partial c}{\partial t}\left(D_{p} \frac{\partial}{\partial z}\left(\frac{\partial c}{\partial z}\right)\right)=0,0 \leq z \leq d(x, t),
$$

and

$$
\begin{aligned}
& M(x, z, t)=0, z \leq d(x, t), \\
& M(x, z, t)=M_{i}, z>d(x, t),
\end{aligned}
$$

where $M_{i}$ is the mineral concentration ahead of the front (unreacted rock).

Rajaram and Arshadi [2016] report all details of the derivation of the similarity solution to equations (5), (7), and (8). They argue that when $t \gg x / v$ where $v Q_{\text {flow }} / W b$, the front behavior is well approximated by dropping the transient term in (5) and quasi steady state conditions apply. This is also justified by a slow rate of mineral depletion. Incorporating these simplifications, the final form of the position of the reactive front in the rock matrix is

$$
d(t, x)=\sqrt{2 n \frac{D_{p} c_{0}}{q_{0} f} t} \frac{2 n D_{p} x W}{Q_{\text {flow }}} .
$$

Note that Sidborn and Neretnieks [2007, equation (4)] and Rajaram and Arshadi [2016, equation (9)] are equivalent when $D_{e} \quad D_{p} n$. We use equations (4)-(9) to model the propagation of the redox fronts across the veins with different values for $D_{e}$.

\subsubsection{Alteration Parallel to the Topography}

The depth of penetration of a continuous redox diffusion front moving downward from the topographic surface into a jointed rock mass is a function of the joint spacing (0.1-1 m observed in outcrop), the width of the alteration halo into the matrix at the fracture inlet, and the depth for DO depletion in the fracture (Figure 2b). The homogenization depth of the alteration halo $Z_{\text {hom }}$ is the depth at which the alteration halo is continuous by the merging of the alteration halos propagating from individual joints,

$$
Z_{\text {hom }}=\frac{Z_{\text {Odep }}\left(d_{\text {inlet }} \frac{s}{2}\right)}{d_{\text {inlet }}},
$$

where $d_{\text {inlet }}[\mathrm{m}]$ is the width of the alteration halo into the matrix at the fracture inlet, $Z_{\text {Odep }}[\mathrm{m}]$ is the depletion depth for the DO in the fracture, and $S[\mathrm{~m}]$ is the joint spacing (Figure $2 \mathrm{~b}$ ).

\subsubsection{Timing of Fracture Flow}

Some of the fractures have complete or partial fillings of hydroxide minerals. We use these fillings to estimate for how long the fractures were open to flow using simple calculations and assuming an instantaneous reaction process in the fracture (i.e., bacterial oxidation) as well as a stationary concentration gradient from the porous matrix and the fracture (stationary state). In particular, we consider a concentration gradient over the half-spacing of the joints. For modeling purposes, we explore the whole range of $\mathrm{Fe}^{2+}$ concentrations measured in the pore water of reducing aquifers, which is variable from 0.1 to $50 \mathrm{mg} / \mathrm{L}$, and then we focus on the range $5-10 \mathrm{mg} / \mathrm{L}$, which includes the most typical values [Appelo and Postma, 2005]. As first-order approximation to calculate the thickness $T(t)$ of the filling material deposited through time on the fracture walls, we use the first law of Fick [Domenico and Schwartz, 1998]. Under the above assumptions, $T$ [m] equals

$$
T=\frac{D_{e} \frac{\partial c_{F 2^{2}}}{\partial z}}{\rho_{g o e} f_{F e}} t,
$$

where $D_{e}\left[\mathrm{~m}^{2} \mathrm{~s}^{1}\right]$ is the effective diffusion coefficient for $\mathrm{Fe}^{2+}$ in the porous medium and $\mathrm{cFe}^{2+}\left[\mathrm{mg} \mathrm{m}^{3}\right]$ is the concentration of $\mathrm{Fe}^{2+}$ in the pore water. Furthermore, $\rho_{\text {goe }}\left[\mathrm{mg} \mathrm{m}^{3}\right.$ ] is the density of the mineral 
hydroxide goethite (given its crystalline form, goethite is the most likely iron hydroxide to be found in a fracture opening), $f_{\mathrm{Fe}}$ is the fraction of iron in the mineral hydroxide, and $t[\mathrm{~s}]$ is the time. The concentration gradient $\frac{\partial c_{\mathrm{Fe}^{2+}}}{\partial z}$ is computed over half of the joint spacing $\left(\frac{5}{2}\right)$.

\subsection{Outcrop Characterization}

We documented fracture type, geometry, relationships among fractures as well as the geometry, and nature of alteration halos around fractures on the surface outcrop by using photo mosaics from high-resolution digital photographs (5-15 megapixels) at a scale from 1:1 to 1:20. We constructed the smaller scale (1:20) overview maps using a rectangular grid with ruled tapes directly on the outcrop surface and then by mapping the structures on mm-scale ruled paper. The field maps were digitized and imported in Adobe Photoshop $^{T M}$. The width ( $d$ in Figure $2 a$ ) of the reactive fronts was measured with a ruler on the outcrop or on enlargements of the photographs. The orientation of the fractures and reactive fronts were measured with a Brunton ${ }^{\mathrm{TM}}$ geologic compass.

\subsection{Petrophysics and Petrography}

The petrophysical properties derive from direct measurements (i.e., porosity) or from the application of wellestablished relationships and typical values for this type of sandstones and tectonic setting [Domenico and Schwartz, 1998; Ingebritsen and Sanford, 2006; Kresic, 2006]. The porosity of the sandstone was mea-sured in the lab by weight difference via imbibition with water and oven drying at $105^{\circ} \mathrm{C}$ of six different samples belonging to the rock inside (three samples) and outside (three samples) the alteration halo. Point counting a large thin section $(10 \times 7 \mathrm{~cm})$ of a rock slab containing both an alteration halo and pristine sandstone provided 2-D porosity values for comparison with the direct measurements. The tortuosity cho-sen was 1.5, which is typical for a medium-grained sandstone [Kresic, 2006]. The average effective diffusion coefficient for DO was derived from the average of the diffusion coefficient at 0 and $24^{\circ} \mathrm{C}$ and then by multi-plying for the porosity $n$ and dividing by the tortuosity $\tau$ as suggested by Kresic [2006].

The mineralogical composition of the MOV Fm was measured by petrographic analysis on a large $(10 \times 7$ $\mathrm{cm}$ ) thin section by 900 random point counts in the altered and unaltered portion of the rock. The individual minerals were recognized based on their optical characteristics. The minerals and framework components identified were monocrystalline quartz, polycrystalline quartz, feldspar, mica (biotite and chloritoid), iron oxides, pyrite (opaque mineral), rock fragments (clay and igneous), and pore fillings (calcite). There were also empty pores. The average grain size of the sandstone was measured optically during point counting (medium grain size $0.2-0.6 \mathrm{~mm}$ ). The molecular weights, mineralogical composition, and density of the minerals recognized during the thin section analysis were obtained from www.webmineral.com.

\section{Results}

\subsection{Outcrop Characterization}

We observed three different fracture types in the outcrop (Figure 3), namely joints (mode I fractures), veins (mode I fractures), and faults (mode II-III fractures). The joints observed in the outcrop are open or partially filled by iron hydroxides (goethite). Their opening is generally small (microscope observations), mostly around 10-100 $\mu \mathrm{m}$; a few of the longest fractures $(>5 \mathrm{~m}$ ) have an opening (or partial filling) around 0.5-1 $\mathrm{mm}$. We observed three systematic sets of joints with trends $\mathrm{N} 115^{\circ} \mathrm{E}, \mathrm{N} 150^{\circ} \mathrm{E}, \mathrm{N} 200^{\circ} \mathrm{E}$ that are all vertical or subvertical (Figure 3). The $\mathrm{N} 200^{\circ} \mathrm{E}$ trending joints abut against the joints with trend $\mathrm{N} 115^{\circ} \mathrm{E}$. The $\mathrm{N} 150^{\circ} \mathrm{E}$ trending joints interact with the $\mathrm{N} 115^{\circ} \mathrm{E}$ trending ones by breaking down in many short segments (Figure 3). The length of the joints varies from 0.05 to $7 \mathrm{~m}$. Joint spacing varies from 0.05 to $5 \mathrm{~m}$; most common spacing is $0.1-1 \mathrm{~m}$. All observed joints have an alteration halo.

The veins in the outcrop have a calcite $\left(\mathrm{CaCO}_{3}\right)$ filling with a thickness varying from 0.5 to $5 \mathrm{~mm}$ (Figure $4 \mathrm{a}$ ). In certain locations, they have an en-echelon arrangement (Figure 3). The veins have varying orientations with trends from NW-SE to NE-SW and dips that are usually vertical or subvertical $\left(80-90^{\circ}\right)$. The length of the veins varies from 0.5 to $4 \mathrm{~m}$. Vein spacing varies from 0.2 to $1 \mathrm{~m}$. Veins are consistently cut by the joints and there are no alteration halos around them (Figure 3). Veins, however, affect the geometry of the alter-ation halo associated with the joint traces (Figure 4a).

A single set of small normal faults is present in the outcrop (Figure 3). Their average orientation is $\mathrm{N} 124^{\circ} \mathrm{E} / 36^{\circ}$ (dip azimuth/dip), which is very close to the orientation of the stratification $\left(\mathrm{N} 120^{\circ} \mathrm{E} / 35^{\circ}\right)$. The spacing in between 


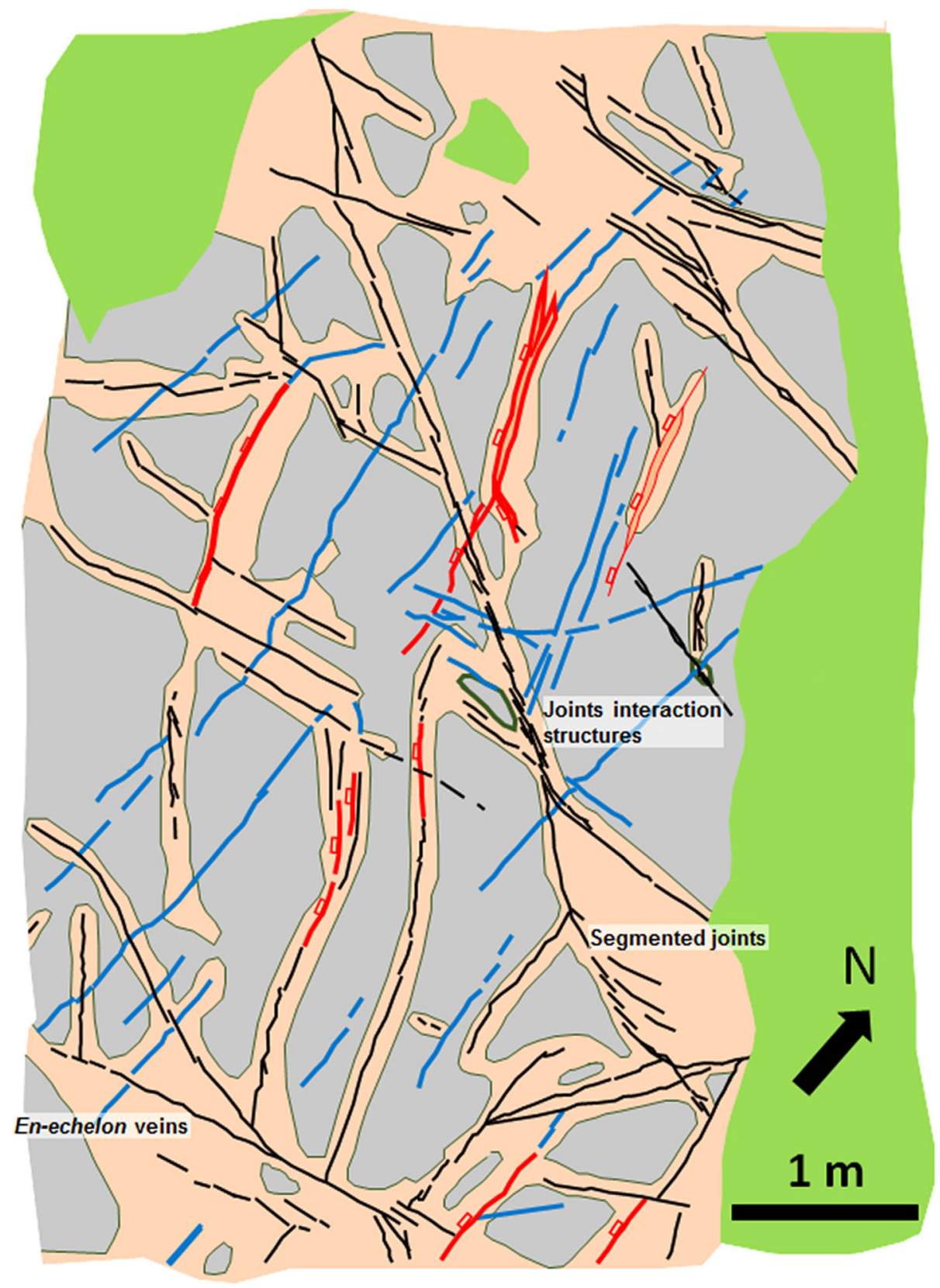

\section{Legend}

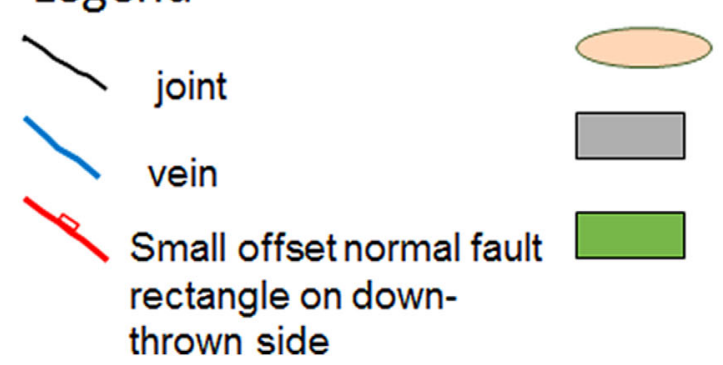

Alteration halos and oxidized sandstone matrix Pristine sandstone matrix

Vegetation cover

Figure 3. Map of a portion of the outcrop showing the different types of fractures and their relationships. Note the alteration halos associ ated with the joints and with some of the small offset normal faults. No alteration halos are associated with the veins. 

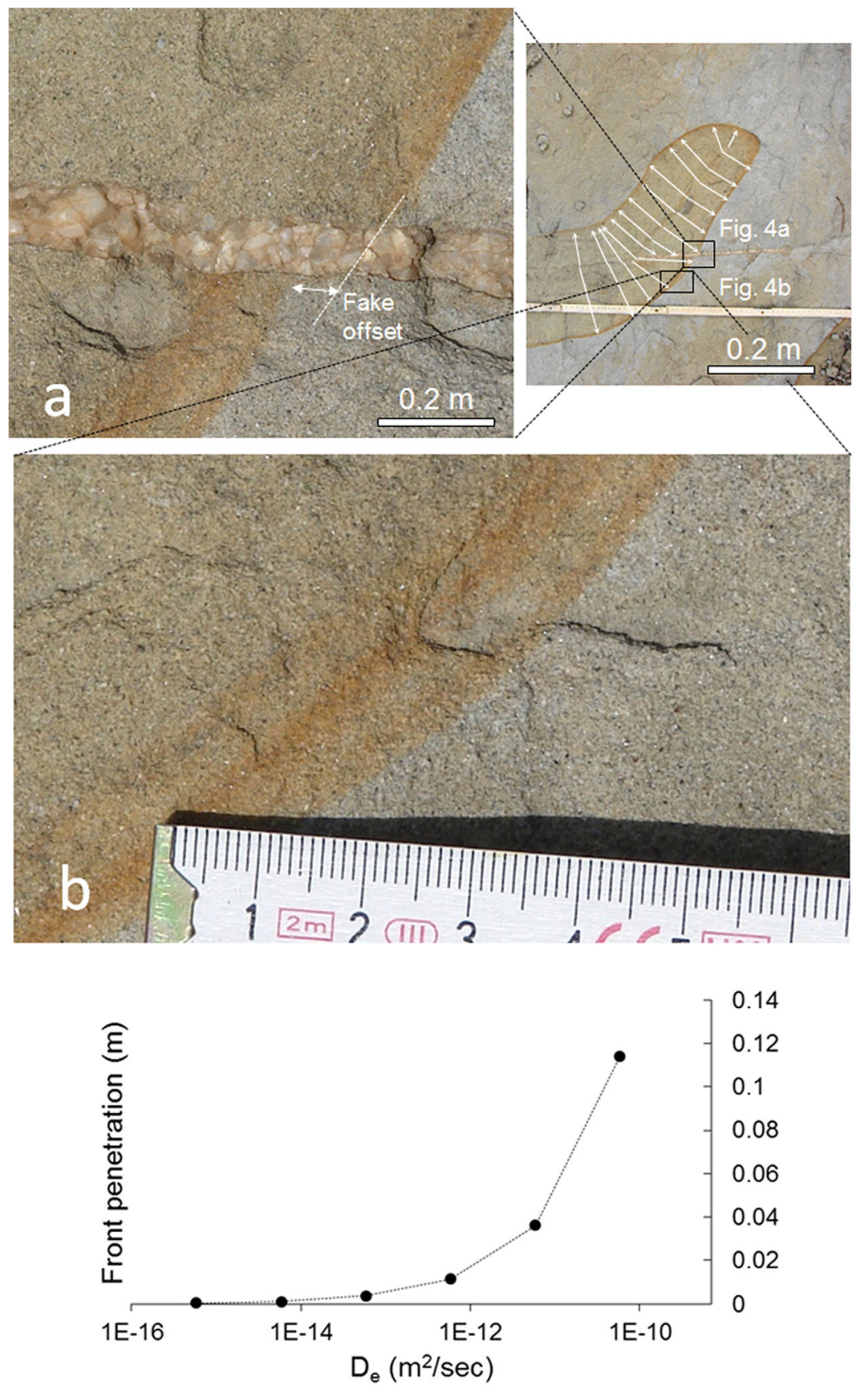

C

Figure 4. Details of the alteration halos. The inset on the right shows the location of $(a, b)$ the diffusion from the open joints (thin white arrows), and the barrier created by the vein. (a) A $5 \mathrm{~mm}$ thick vein affects the propagation of the alteration halo. Note the fake offset of the alteration halo boundary. (b) Detail of the alteration halo boundary. The halo boundary is a $15 \mathrm{~mm}$ wide band. The central part of the band ( $5 \mathrm{~mm}$ wide) has a stronger orange brown coloration than the rest of the band. (c) Width of the alteration halo at 5000 years computed with equations (4) (9) as a function of different values for the effective diffusivity $D_{e}$ in the rock matrix. Note that for the vein to prevent diffusion as observed in Figure $4 a, D_{e}$ in the vein should be 35 orders of magnitude smaller than the $D_{e}$ in the rock matrix.

the faults varies from 0.5 to $1.5 \mathrm{~m}$ (Figure 3 ) and their length from 0.3 to $1.5 \mathrm{~m}$ (Figure 3). Some faults are associated with an alteration halo and some are not; in any case, there are orange-brown stains on their slip surfaces.

\subsection{Alteration Halos}

Around all joint traces, we observed a more or less elliptical area of sandstone with a brownish-orange color. Darker orange-brown bands about 5-15 mm thick (Figure 5) make up the boundary of the alteration 
halo. Where the joint is isolated in the rock matrix, the alteration halo has a regular subelliptical shape in 2-D-an oblate ellipsoid in 3-D (Figures $5 a$ and $5 c$ ). The edge of the alteration halo follows any change in direction of the joint trace (Figures $5 \mathrm{~b}$ and $5 \mathrm{~d}$ ). Where joint segments overlap or are closely spaced, the areas of oxidized sandstone also overlap and tend to form wider zones than along the individual joints (Figure 5b). Where the joints step laterally, the elliptical alteration halos also step laterally (Figure 5e). The altered areas consist of three concentric zones (Figures $5 \mathrm{c}$ and $5 \mathrm{~d}$ ): (1) the sandstone in the zone closest to the joint trace has a pale reddish-brown color; (2) the second concentric zone is 1-1.5 cm thick and consists of sandstone with an intense reddish-brown color and a few lineations of dark colored (brown-orange) minerals parallel to the boundary zone (Figure 4b); (3) the third area is the unaltered rock matrix outside the alteration halo and has a gray color (Figures $5 \mathrm{c}$ and $5 \mathrm{~d}$ ). The width of the altered area is rather homogeneous along the individual joint and it varies within a limited range (4-12 cm; Figure 6a) from joint to joint. Figure $6 a$ shows the relationship between alteration halo width and joint length (114 data points) measured on the sandstone pavement (fracture inlet) (Figure 3). The average value for alteration halo width is $0.083 \mathrm{~m}$ with a standard deviation $(\sigma)$ of $0.0168 \mathrm{~m}$. The average joint length is $1.93 \mathrm{~m}$ with a standard deviation of $1.73 \mathrm{~m}$. Figure $6 \mathrm{~b}$ shows the relationship between alteration halo width and fracture opening. The average joint opening is $0.00021 \mathrm{~m}$ with a standard deviation of $0.00071 \mathrm{~m}$.
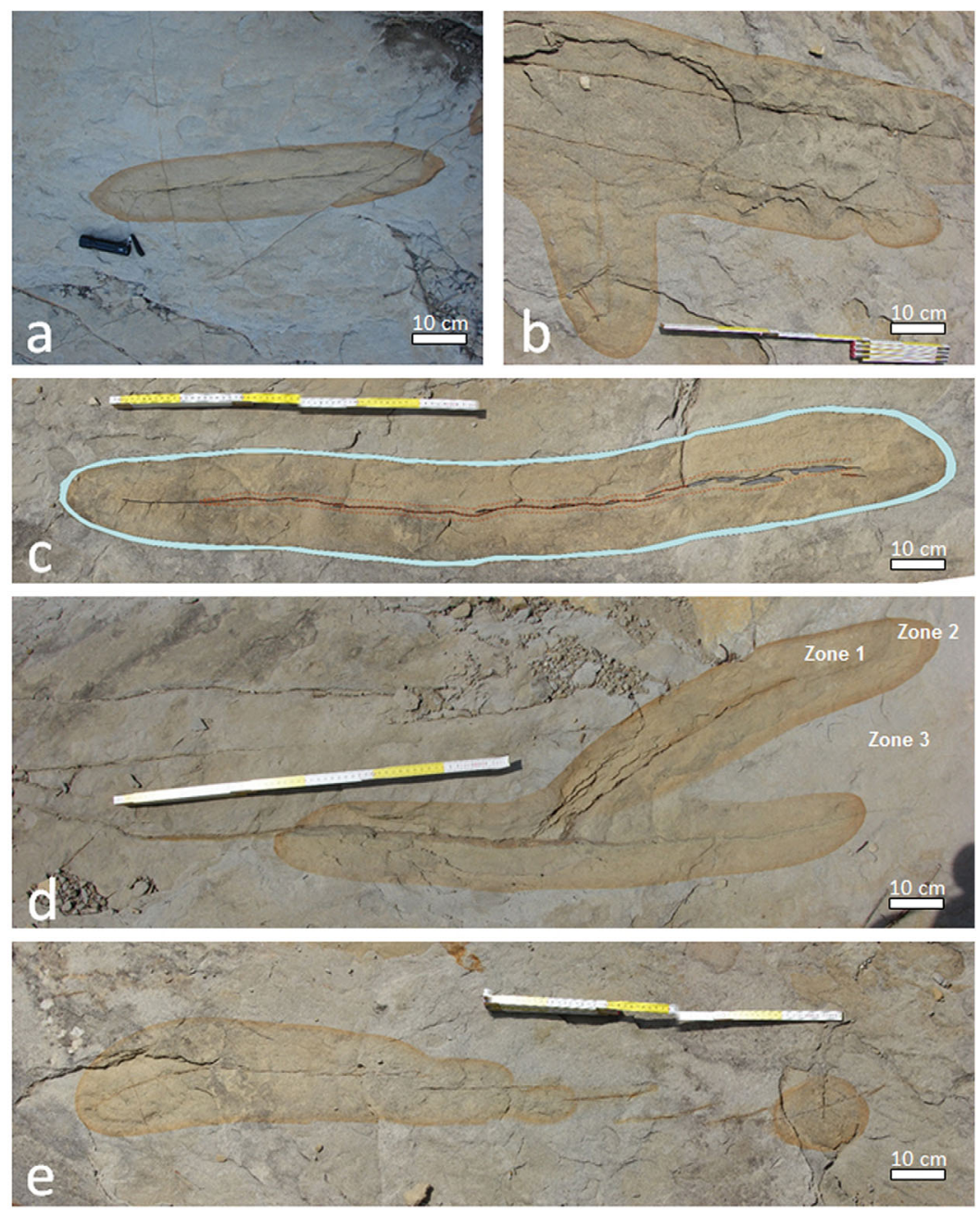

Figure 5. Examples of alteration halos. (a) Elliptical shape of an alteration halo around an isolated joint. The joint trace consists of overlap ping smaller joint segments. Two veins, one at high angle and one at low angle to the joint trace, cut the alteration halo. (b) The matrix in between the closely spaced parallel joints has an orange brown coloration. (c) The different parts of the alteration halo are shown. The outer part of the halo (light blue) has a strong coloration as in Figure $4 \mathrm{~b}$. The dashed red line marks a secondary halo, which is not present along the whole extension of the joint trace. The gray areas mark small stepping joints at the fracture termination. (d) At a joint termina tion, the alteration halo forms both along the joint trace and on a wing crack oriented at an angle of $6570^{\circ}$ from the joint trace. (e) Alter ation halos follow the short joint steps. 

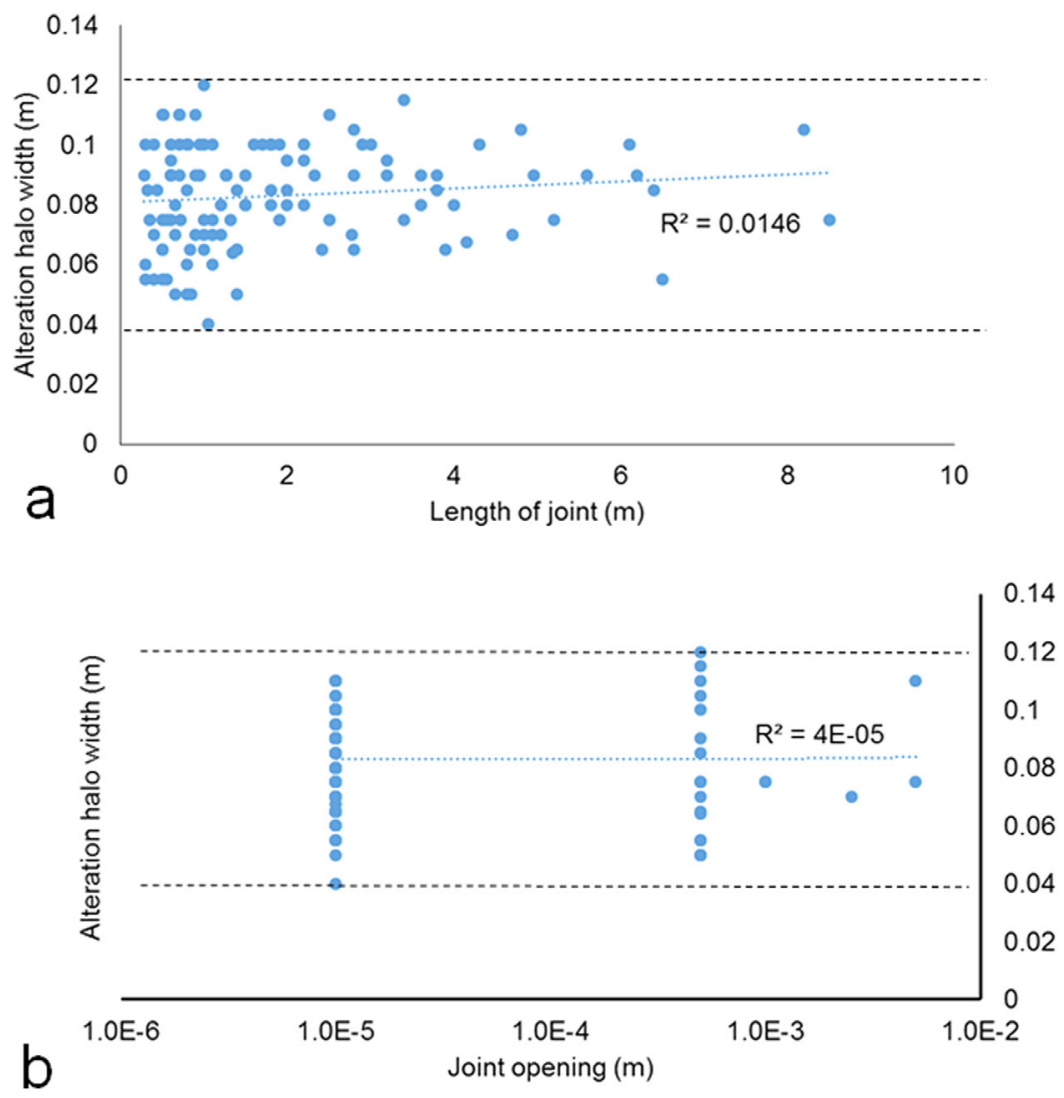

Figure 6. Relationships (a) between alteration halo width and joint length and (b) between alteration halo width and joint opening (or hydroxide filling). There are 114 data points from the sandstone pavement. The halos are at the fracture inlets. Average alteration halo widths, joint openings, and lengths are $0.083,0.00021$, and $1.93 \mathrm{~m}$. The corresponding standard deviations are $0.0168,0.00071$, and $1.73 \mathrm{~m}$

The morphology of the alteration halo boundary is regular, relatively sharp, and continuous except where it encounters one of the calcite-filled veins. In this case, there is perturbation of the alteration halo boundary (see Figure 4a). The vein seems to act as a barrier to the propagation of the alteration halo; in some locations, there is a fake offset of the alteration halo boundary across the vein (Figures $4 \mathrm{a}$ and $5 \mathrm{a}$ ). Most alteration halos are parallel to the lithological bedding and seem to propagate away from and perpendicular to the surface of the outcrop (Figures $7 \mathrm{a}$ and $7 \mathrm{~b}$ ), which is also a bedding plane; these alteration halos do not penetrate the sandstone more than 0.2-0.4 $\mathrm{m}$ from the topographic surface (Figure 7a). Where different sets of joints abut or cross cut each other, the area of oxidation widens following the breaking down of the joints segments or the trace of wing cracks (Figure 7c).

The width of all alteration halos along the joints decreases with depth from the inlet (away from the topographic surface). Figure 8 shows this relationship. We were able to measure or estimate the relationship between alteration halo width and depth normal to the inlet on a few bedding surfaces and vertical cuts (normal to bedding). The maximum depth investigated, however, did not exceed 0.05-0.3 $\mathrm{m}$ from the pavement surface (Figure $8 \mathrm{~b}$ ). Figure $8 \mathrm{c}$ shows a $3-\mathrm{D}$ outcrop that documents this relationship.

\subsection{Rock Composition}

The composition of the rock obtained from point counting is the same in the alteration halo and in the unaltered rock: an arkose. The grain size is typical for a medium-grained sand with average grain diameter of $0.2 \mathrm{~mm}$ (see Table 1 for results of point counting). Chloritoid, biotite (biotite + chloritoid 6.15\%), and pyrite $(0.77 \%)$ are the minerals that contain the $\mathrm{Fe}^{2+}$ used for oxidation. The rock density computed from the average mineral composition in Table 1 is $2.65 \mathrm{~g} / \mathrm{cm}^{3}$. Based on the rock composition obtained, the oxidation reaction imparting the orange-brown coloration in the alteration halos is [Sidborn and Neretnieks, 2007] 

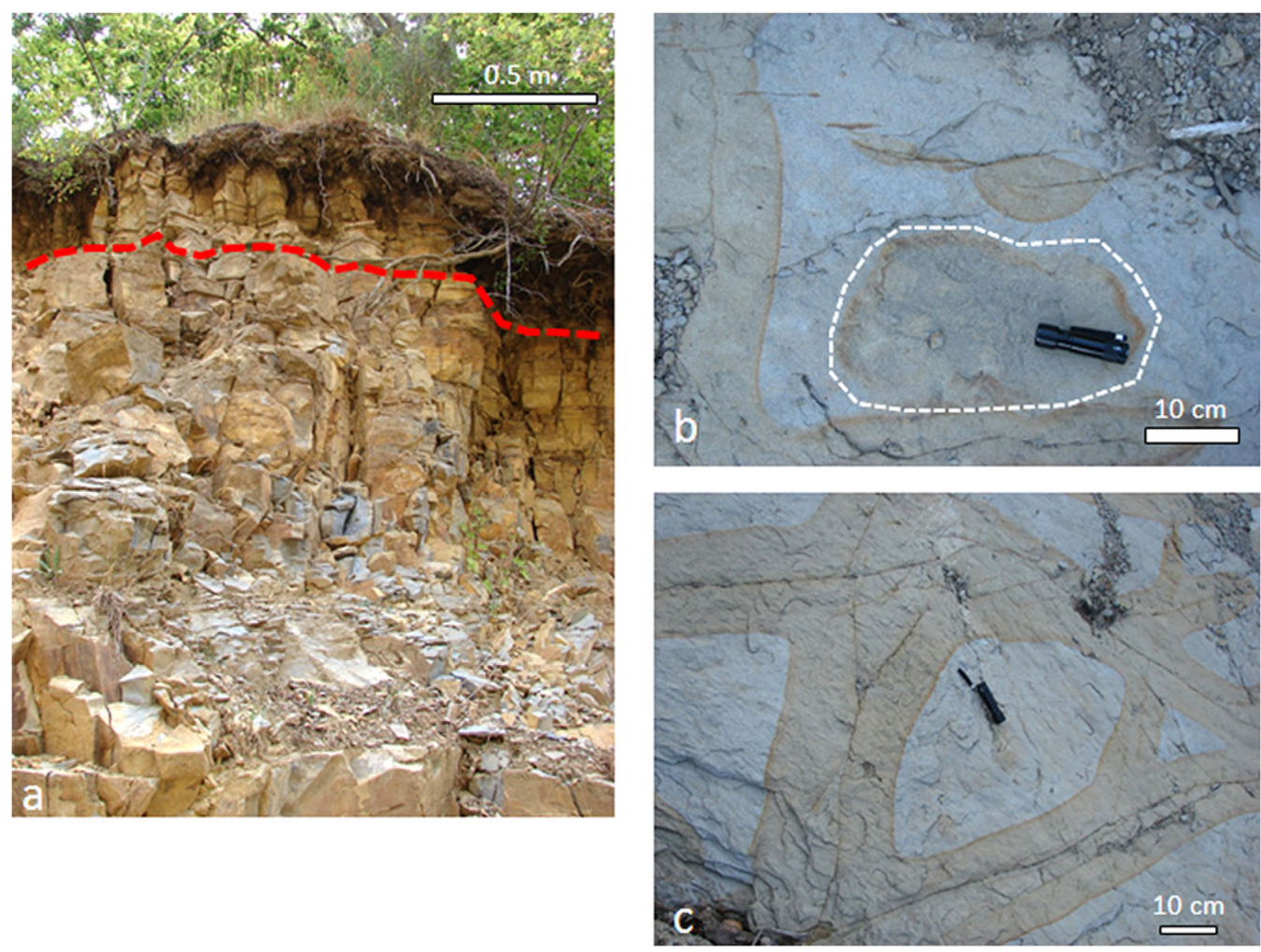

Figure 7. Examples of different alteration halo types and their interactions. (a) View of the weathering profile (oxidation) on an outcrop face. The dashed red line marks the penetration of a homogeneous alteration halo propagating from the surface. Below the dashed red line, the alteration halos are only associated to the fractures. Note the different spacing of the joints in the different sedimentary layers; the joint spacing correlates with bed thickness. (b) Bedding parallel (dashed white line) alteration halo propagating from the topo graphic surface. The soil cover here is less than $0.2 \mathrm{~m}$. (c) Wide alteration zones in the sandstone at the intersection among different joint sets.

$$
\mathrm{Fe}^{2+}+0.25 \mathrm{O}_{2}+2.5 \mathrm{H}_{2} \mathrm{O} \rightarrow \mathrm{Fe}(\mathrm{OH})_{3(\mathrm{~s})}+2 \mathrm{H}^{+}
$$

\subsection{Petrophysical Properties}

Tables 2 and 3 summarize the measurements of the petrophysical properties in the host rock, the fractures, and the physical-chemical properties of the elements and minerals. The flow rate in the fractures, which is the most unconstrained parameter, was obtained by matching the slope of the linear relationship between alteration halo width and depth from the inlet as measured in the outcrop (Figure 8b) with the theoretical slope in the analytical solutions of Sidborn and Neretnieks [2007] and Rajaram and Arshadi [2016].

\subsection{Analytical Modeling}

Figures 9 and 10 show the analytical modeling results for the inlet area (Figure 2a) of the fracture and at depth, respectively. The penetration distances of the alteration halo in the MOV sandstone at the fracture inlet as a function of time according to the Sidborn and Neretnieks [2007, equation (3)] and the Rajaram and Arshadi [2016, equation (9)] solutions are shown in Figure 9. Given that the two solutions are equivalent, from now on we will just refer to the "analytical solutions." Three different effective diffusivities in the rock matrix are considered: $D_{e}(\min ) \quad 1.60 \mathrm{E}-11 \mathrm{~m}^{2} / \mathrm{s}\left(n \quad 0.02 ; \tau \quad 1.5 ; D_{o}\right.$ at $\left.0^{\circ} \mathrm{C}\right), D_{e}(\operatorname{avg}) \quad 5.83 \mathrm{E}-11 \mathrm{~m}^{2} / \mathrm{s}$ (n $\quad 0.05 ; \tau \quad 1.5 ; D_{o}$ at $12^{\circ} \mathrm{C}$ ), and $D_{e}(\max ) \quad 1.23 \mathrm{E}-10 \mathrm{~m}^{2} / \mathrm{s}\left(n \quad 0.08 ; \tau \quad 1.5 ; D_{o}\right.$ at $24^{\circ} \mathrm{C}$ ). A penetration distance of $0.1-0.12 \mathrm{~m}$ around the fracture inlet is typical for the situations observed in outcrop (Figures $6 \mathrm{a}$ and $8 \mathrm{~b}$ ). By using $D_{e}(\mathrm{~min})$ in the analytical solutions, the alteration halo width observed would correspond to fluid circulation starting 14,000-21,000 years before present at the end of the last ice age-Wúrm glacial period. By using $D_{e}(a v g)$, the alteration halo width observed would correspond to fluid circulation starting 4000-5500 years before present in the middle of the Holocene period. By using $D_{e}(\max )$, the alteration halo width observed would correspond to fluid circulation starting 2000-2500 years before present (late Holocene). 

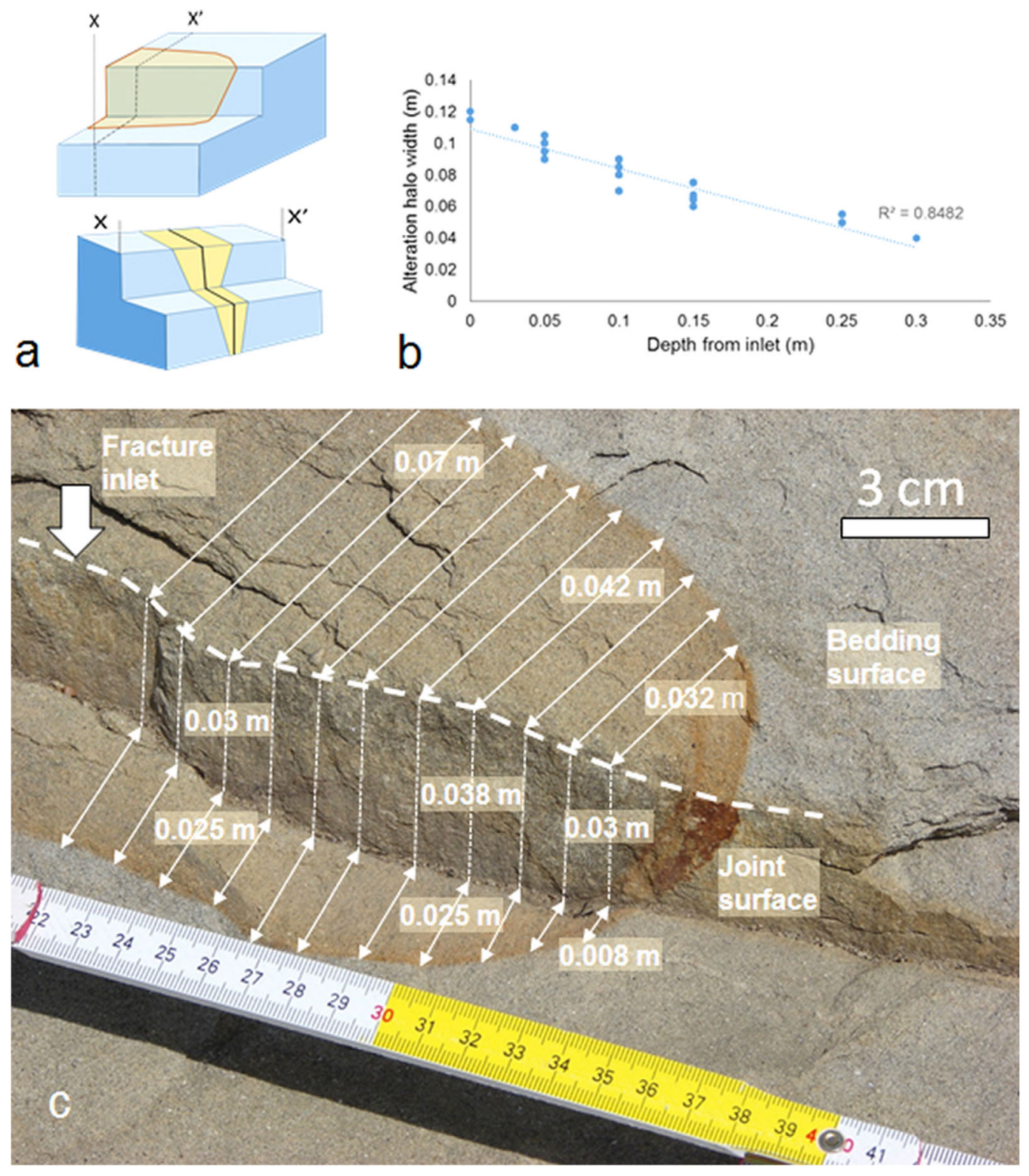

Figure 8. Relationship between width of the alteration halo and distance from the (original) topographic surface (fracture inlet). (a) The block diagrams explain the geometry of the system. The upper block diagram represents the actual cut in Figure $8 \mathrm{c}$. (b) The relationship between alteration halo width and depth from the inlet as measured in the outcrop (109 data points). Average alteration halo widths and depths from the inlet are 0.083 and $0.104 \mathrm{~m}$. The corresponding standard deviations are 0.0168 and $0.062 \mathrm{~m}$. (c) Three dimensional rock cut showing the decrease in alteration halo width with depth from the inlet. The white arrows indicate some selected measurements for scale.

The penetration depth of the alteration halo (width of the alteration halo observed in outcrop) into the porous matrix of the MOV Fm sandstone downstream of the fracture inlet at 1700, 2000, 2500, and 2700 years, respectively, is plotted in Figure 10a for the analytical solutions (equations (4) and (9)) and $D_{e}(\max )$. On the same plot, we report the field data (width of alteration the halo versus distance downstream from the fracture inlet). From the linear interpolation $\left(R^{2}\right.$ 0.8482) of the field data, we can estimate the flow rate in the fracture $\left(Q_{\text {flow }} \quad 9.50 \mathrm{E}-10 \mathrm{~m}^{3} / \mathrm{s}\right.$; see Table 2$)$. This is the least constrained parameter in equations (4) and (9). At 1700 years, the penetration depth into the matrix drops to zero at a distance downstream of $0.38 \mathrm{~m}$ from the fracture inlet (Figure 10a). At 2000 years, the penetration depth into the matrix drops to zero at a distance downstream of $0.41 \mathrm{~m}$ from the fracture inlet (Figure 10a). At 2700 years, the penetration depth is zero at a distance downstream of $0.48 \mathrm{~m}$ from the fracture inlet (Figure 10a). The average of the field data $(0.083 \mathrm{~m}$ width at a $0.104 \mathrm{~m}$ distance downstream) and the best fit to the linear interpolation line 
Table 1. Sandstone Composition From Thin Sections Point Counting

\begin{tabular}{lcc} 
Rock Component & Formula & \% Volume \\
\hline Monocrystalline quartz & $\mathrm{SiO}_{2}$ & 33.08 \\
Mon. quartz und. ext. & $\mathrm{SiO}_{2}$ & 15.77 \\
Polycrystalline quartz & $\mathrm{SiO}_{2}$ & 8.46 \\
Polyc. quartz und. ext. & $\mathrm{SiO}_{2}$ & 7.31 \\
Feldspar & $\mathrm{KAISi}_{3} \mathrm{O}_{8}$ & 14.62 \\
Mica (biotite, chloritoid) & & 6.15 \\
Iron oxides & & 0.77 \\
Pyrite (opaque) & & 0.77 \\
Rock fragment (clay) & $\mathrm{FeS}_{2}$ & 1.54 \\
Rock fragment (igneous) & & 1.54 \\
Pore filling (calcite) & & 7.69 \\
Pore & $\mathrm{CaCO}_{3}$ & 2.31 \\
Total & & 100 \\
\hline
\end{tabular}

aNote that the presence of pyrite is inferred given that it shows up as an opaque mineral in thin section. to the field data fall on the $t \quad 2200 \pm 500$ years line. The uncertainty ( \pm 500 years) derives from the range variation of alteration halo width measured in outcrop.

The penetration depth of the alteration halo into the porous matrix of the MOV Fm sandstone downstream of the fracture inlet at 3000, 4000, 5000, and 6000 years, respectively, is plotted in Figure 10b using $D_{e}(a v g)$ in the analytical solutions (equations (4) and (9)). The estimated flow rate in the fracture is $Q_{\text {flow }} 4.60 \mathrm{E}-10 \mathrm{~m}^{3} / \mathrm{s}$ (Table 2). At 3000 years, the penetration depth into the matrix drops to zero at a distance downstream of $0.36 \mathrm{~m}$ from the

fracture inlet (Figure 10b). At 4000 years, the penetration depth into the matrix drops to zero at a distance downstream of $0.42 \mathrm{~m}$ from the fracture inlet (Figure 10b). At 6000 years, the penetration depth is zero at a distance downstream of $0.51 \mathrm{~m}$ from the fracture inlet (Figure 10b). The average of the field data $(0.083 \mathrm{~m}$ width at a $0.104 \mathrm{~m}$ distance downstream) and the best fit to the linear interpolation line to the field data falls on the $t \quad 4600 \pm 900$ years line.

The penetration depth of the alteration halo into the porous matrix of the MOV Fm sandstone downstream of the fracture inlet at 12,000,15,000, 18,000, and 20,000 years, respectively, is plotted in Figure 10 c using $D_{e}(\mathrm{~min})$ in the analytical solutions (equations (4) and (9)). The estimated flow rate in the fracture is $Q_{\text {flow }} 1.30 \mathrm{E}-10 \mathrm{~m}^{3} / \mathrm{s}$ (Table 2). At 12,000 years, the penetration depth into the matrix drops to zero at a distance downstream of $0.375 \mathrm{~m}$ from the fracture inlet (Figure 10c). At 15,000 years, the penetration depth into the matrix drops to zero at a distance downstream of $0.425 \mathrm{~m}$ from the fracture inlet (Figure 10c). At 20,000 years, the penetration depth is zero at a distance downstream of $0.49 \mathrm{~m}$ from the fracture inlet (Figure 10c). The average of the field data $(0.083 \mathrm{~m}$ width at a $0.104 \mathrm{~m}$ distance downstream) and the best fit to the linear interpolation line to the field data fall on the $t \quad 16,000 \pm$ 4000 years line.

The depth of penetration $\left(Z_{\text {hom }}\right)$ of a continuous redox diffusion front moving downward from the topographic surface computed from equation (10) and for the characteristic joint spacing observed in the outcrops is presented in Table 4. The joint spacing in the map of Figure 3 varies from 0.1 to $1 \mathrm{~m}$, whereas in Figure $7 \mathrm{~b}$ it varies between 0.05 and $0.1 \mathrm{~m}$. The other parameters (time and DO depletion depth) are obtained from the analytical solutions (equations (3), (4), and (9)) and $D_{e}$ average.

Table 2. Modeling Parameters for the Monte Venere Formation

\begin{tabular}{|c|c|c|c|c|}
\hline Property & Symbol & Value & Unit & Source/Reference \\
\hline Oxygen concentration in the water at fracture inlet & $c_{0}$ & 0.03 & $\mathrm{~mol} \mathrm{~m}^{-3}$ & Sidborn and Neretnieks [2007] \\
\hline Initial chloritoid + pyrite concentration in the rock & $q_{0}$ & 338 & $\mathrm{~mol} \mathrm{~m}^{-3}$ & This study \\
\hline Stoichiometric factor & $f$ & 0.125 & $\mathrm{~mol} \mathrm{O}_{2} /$ molChlor $+\mathrm{Py}$ & This study \\
\hline Fracture aperture & $2 b$ & 0.00001 & $\mathrm{~m}$ & This study \\
\hline$Q_{\text {flow }}$ & & 4.60E 10 & $\mathrm{~m}^{3} / \mathrm{s}$ & This study; computed for $D_{\mathrm{e}}(a v g)$ \\
\hline$Q_{\text {flow }}$ & & $1.3 \mathrm{E} 10$ & $\mathrm{~m}^{3} / \mathrm{s}$ & This study; computed for $D_{\mathrm{e}}(\mathrm{min})$ \\
\hline$Q_{\text {flow }}$ & & $9.5 \mathrm{E} 10$ & $\mathrm{~m}^{3} / \mathrm{s}$ & This study; computed for $D_{\mathrm{e}}(\max )$ \\
\hline Effective diffusivity in rock matrix (average value) & $D_{\mathrm{e}}$ & 5.83E 11 & $\mathrm{~m}^{2} / \mathrm{s}$ & Kresic [2006]. This study \\
\hline Effective diffusivity in rock matrix (minimum value) & $D_{\mathrm{e}}$ & $1.60 \mathrm{E} 11$ & $\mathrm{~m}^{2} / \mathrm{s}$ & This study \\
\hline Effective diffusivity in rock matrix (maximum value) & $D_{\mathrm{e}}$ & $1.23 \mathrm{E} 10$ & $\mathrm{~m}^{2} / \mathrm{s}$ & This study \\
\hline Diffusion coefficient of $\mathrm{DO}$ at $0^{\circ} \mathrm{C}$ in liquid & $D_{0}$ & $1.20 \mathrm{E} 09$ & $\mathrm{~m}^{2} / \mathrm{s}$ & Sidborn and Neretnieks [2007] \\
\hline Diffusion coefficient of DO at $24^{\circ} \mathrm{C}$ in liquid & $D_{0}$ & 2.30E 09 & $\mathrm{~m}^{2} / \mathrm{s}$ & Sidborn and Neretnieks [2007] \\
\hline Average DO diffusion coefficient in liquid & $D_{\mathrm{o}}$ & $1.75 \mathrm{E} 09$ & $\mathrm{~m}^{2} / \mathrm{s}$ & Sidborn and Neretnieks [2007] \\
\hline Porosity & $n$ & $0.05 \pm 0.03$ & & This study \\
\hline Optical 2 D porosity & & 0.023 & & This study \\
\hline Skeleton porosity (empty pores plus pore filling) & & 0.1 & & This study \\
\hline Tortuosity & $\tau$ & 1.5 & & Kresic [2006] \\
\hline
\end{tabular}


Table 3. Modeling Parameters for Iron Hydroxide Precipitation in the Joint Opening

\begin{tabular}{lccl} 
Property & Value & Unit & Source/Reference \\
\hline Joint spacing & 1 & $\mathrm{~m}$ & This study \\
Fracture area & 1 & $\mathrm{~m}^{2}$ & This study \\
Goethite density & 3800 & $\mathrm{~kg} / \mathrm{m}^{3}$ & webmineral.com \\
$\begin{array}{l}D_{\mathrm{e}} \text { for Fe } \mathrm{Fe}^{2+} \text { in fluids } \\
\text { within rock matrix }\end{array}$ & $5.83 \mathrm{E} 11$ & $\mathrm{~m}^{2} / \mathrm{s}$ & Kresic [2006] \\
Fraction of Fe ${ }^{3+}$ in goethite & 0.6285 & & webmineral.com \\
\hline
\end{tabular}

The thickness $T(t)$ of the hydroxide-filling material deposited through time on the fracture walls for a range of $\mathrm{Fe}^{2+}$ concentrations measured in the pore water of reducing aquifers $(0.1-50 \mathrm{mg} / \mathrm{L})$ is presented in Figure 11; the continuous lines indicate the most likely concentrations [Appelo and Postma, 2005]. The dark shaded area in Figure 11 represents the range in thicknesses observed in the outcrop. For typical $\mathrm{Fe}^{+2}$

concentrations values in the aquifer and the typical filling thicknesses observed in the outcrop (thick red segment in Figure 11), the time-to-fill-starting-time is set to about 6000-10,000 years from present.

\section{Discussion}

\subsection{Origin of the Alteration Halos}

The alteration halos exposed in the outcrop have the two following characteristics: (1) they are symmetrical around the joints; (2) they have similar width where observed on the same bedding surface regardless of which joint set they belong to. The plots in Figure 6 show that there is no relationship between joint length

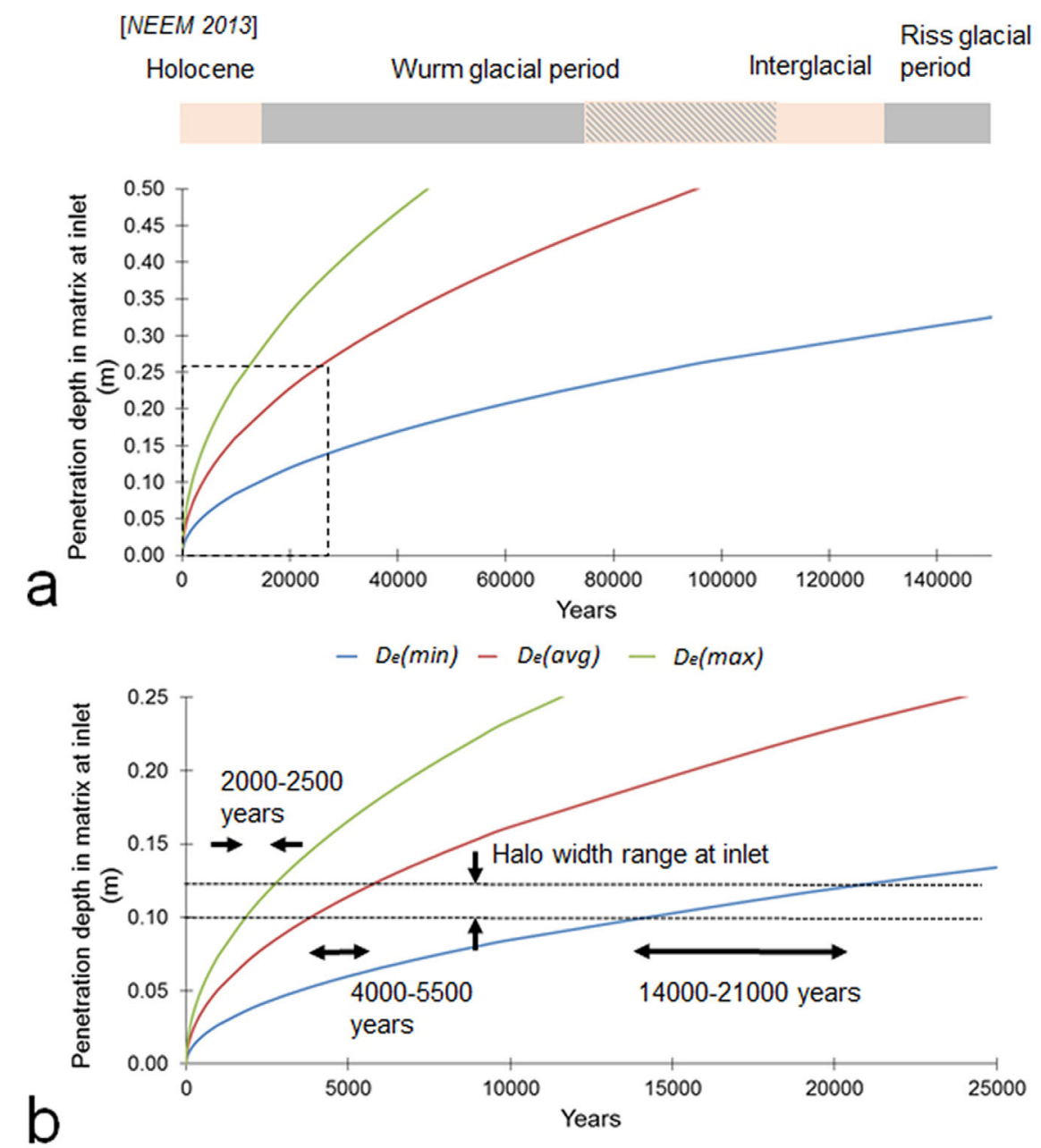

Figure 9. (a) Penetration distance of alteration halo at the fracture inlet as a function of time for the analytical solutions (3) (9). The dashed box represents the portion of the graph enlarged in Figure $9 \mathrm{~b}$. The two horizontal lines on the graph define the range in width of the alter ation halos at the inlet observed in the outcrop. On top, the chronology of ice ages in the alpine area after NEEM Community Members [2013]. 

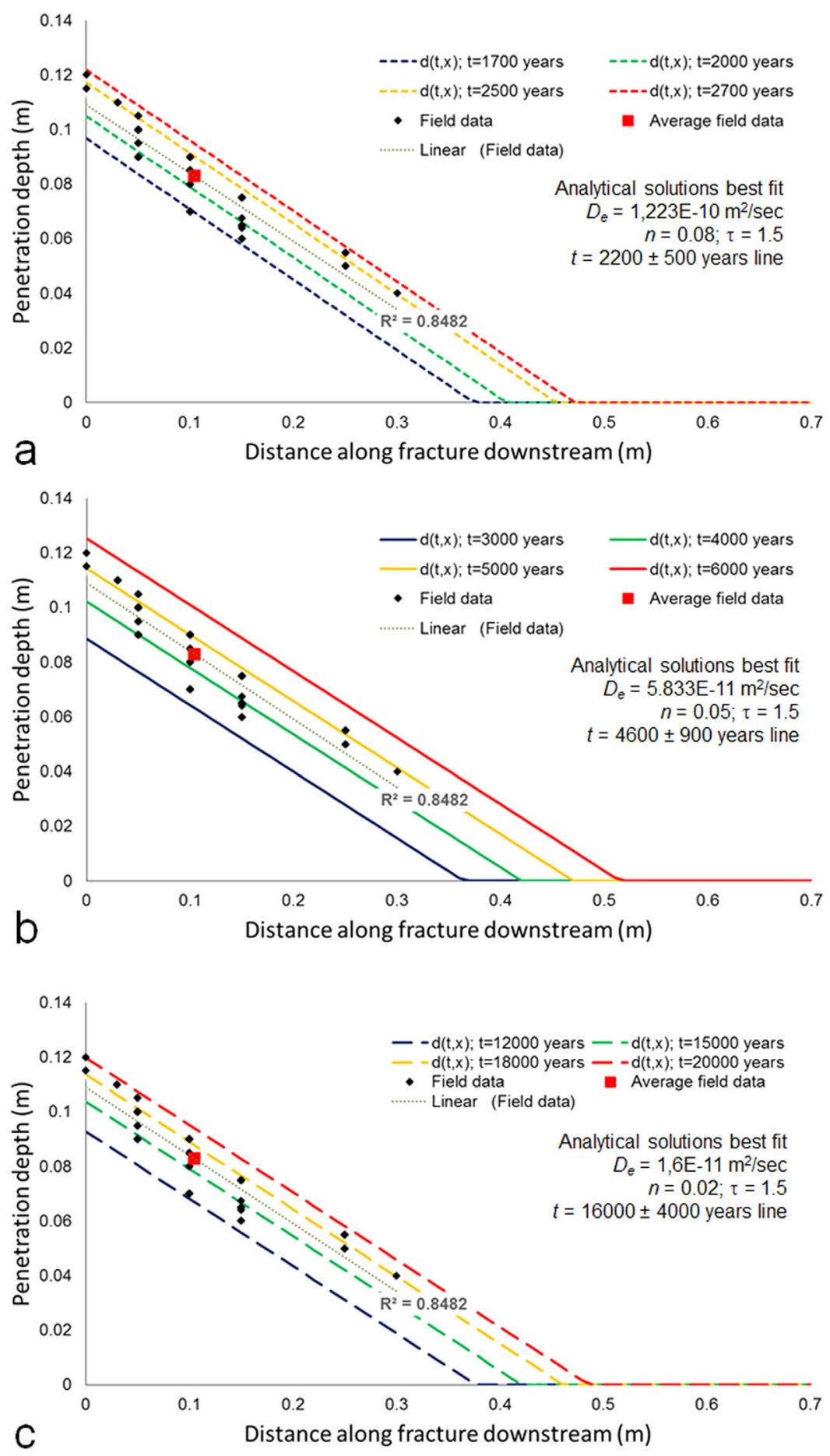

Figure 10. Modeling results (terminology is defined in Figure 2a). Penetration depth of the alteration halo into the porous matrix (width of the alteration halo observed in outcrop) as a function of distance downstream (vertically) from the fracture inlet for different time intervals and $D_{e}$ values. The black dots represent the field data and the red square box is the average of the field data. The thin dotted line is the lin ear interpolation to the field data $\left(\mathrm{R}^{2}=0.8482\right)$. (a) Application of $D_{e}(\max )$ in the analytical solutions. The best fit to the interpolated data is the $t=2200 \pm 500$ years line. (b) Application of $D_{e}(\mathrm{avg})$ in the analytical solutions. The best fit to the interpolated data is the $t=4600 \pm$ 900 years line. (c) Application of $D_{e}(\mathrm{~min})$ in the analytical solutions. The best fit to the interpolated data is the $t=16,000 \pm 4000$ years line.

and alteration halo width ( $R^{2} \quad 0.0146$; Figure 6a) or between joint opening (and/or hydroxide filling) and alteration halo width $\left(R^{2} \quad 0.00004\right.$; Figure $6 \mathrm{~b}$ ). The width of the alteration halos does not depend on joint length or joint opening, which are parameters controlling flow rate: it only depends on the chemical species 


\begin{tabular}{|c|c|c|c|c|}
\hline$S(m)$ & $Z_{\text {hom }}(\mathrm{m}) 3000$ Years & $Z_{\text {hom }}(\mathrm{m}) 4000$ Years & $Z_{\text {hom }}(\mathrm{m}) 5000$ Years & $Z_{\text {hom }}(\mathrm{m}) 6000$ Years \\
\hline 0.05 & 0.25 & 0.32 & 0.37 & 0.41 \\
\hline 0.1 & 0.16 & 0.22 & 0.27 & 0.31 \\
\hline 0.2 & No $Z_{\text {hom }}$ reached & 0.01 & 0.06 & 0.1 \\
\hline 0.3 & No $Z_{\text {hom }}$ reached & No $Z_{\text {hom }}$ reached & No $Z_{\text {hom }}$ reached & No $Z_{\text {hom }}$ reached \\
\hline 0.5 & No $Z_{\text {hom }}$ reached & No $Z_{\text {hom }}$ reached & No $Z_{\text {hom }}$ reached & No $Z_{\text {hom }}$ reached \\
\hline
\end{tabular}

concentration ratio, effective diffusivity in the rock matrix, and time. This is expected from equation (3) [Sidborn and Neretnieks, 2007] and equation (9) [Rajaram and Arshadi, 2016] at the fracture inlet. The width of the alteration halos decreases with depth from the surface, i.e., the inlet of the fracture. This is consistent with the progressive depletion in DO within the fracture as it moves by diffusion into the matrix. These observations suggest that the fluid flow forming the alteration halos was concentrated within the joint and fault network. The symmetry of the alteration halos indicates that there was no advective mass transfer between fracture and matrix. All these characteristics suggest that the alteration halos formed because of mass transfer by diffusion and their outer edges represent redox fronts. Molecular DO dissolved in meteoric water has a concentration of about $9.1 \mathrm{mg} / \mathrm{L}$ at $20^{\circ} \mathrm{C}$ and atmospheric pressure. DO entered the fracture and then moved by diffusion into the porous matrix where reducing conditions prevailed. At the same time, ferrous iron $\mathrm{Fe}^{2+}$ in solution within the pores of the matrix was also moving by diffusion toward the oxic environment in the fracture. The DO encountering the $\mathrm{Fe}^{2+}$ caused the precipitation of a hydroxide mineral (such as the goethite) in the pore space adjacent to the fracture. In the fracture space, hydroxide mineral stains formed via the redox activity of bacteria present in the oxygenated water of the fracture [Yoshida et al., 2006; Sidborn and Neretnieks, 2007; Yang et al., 2008]. Hydroxide minerals impart the characteristic orange-brownish color to the rock (Figures $4 a$ and $4 \mathrm{~b}$ ). This phenomenon is similar to that described extensively for granite rock [Sidborn and Neretnieks, 2007, 2008]. The redox front is relatively sharp (Figure 4b) and marked by a $1 \mathrm{~cm}$ thick band where the orange-brown color is more pronounced and where the hydroxide mineral is more abundant. This band forms because the oxidation rate of $\mathrm{Fe}^{2+}$ ions by DO is not
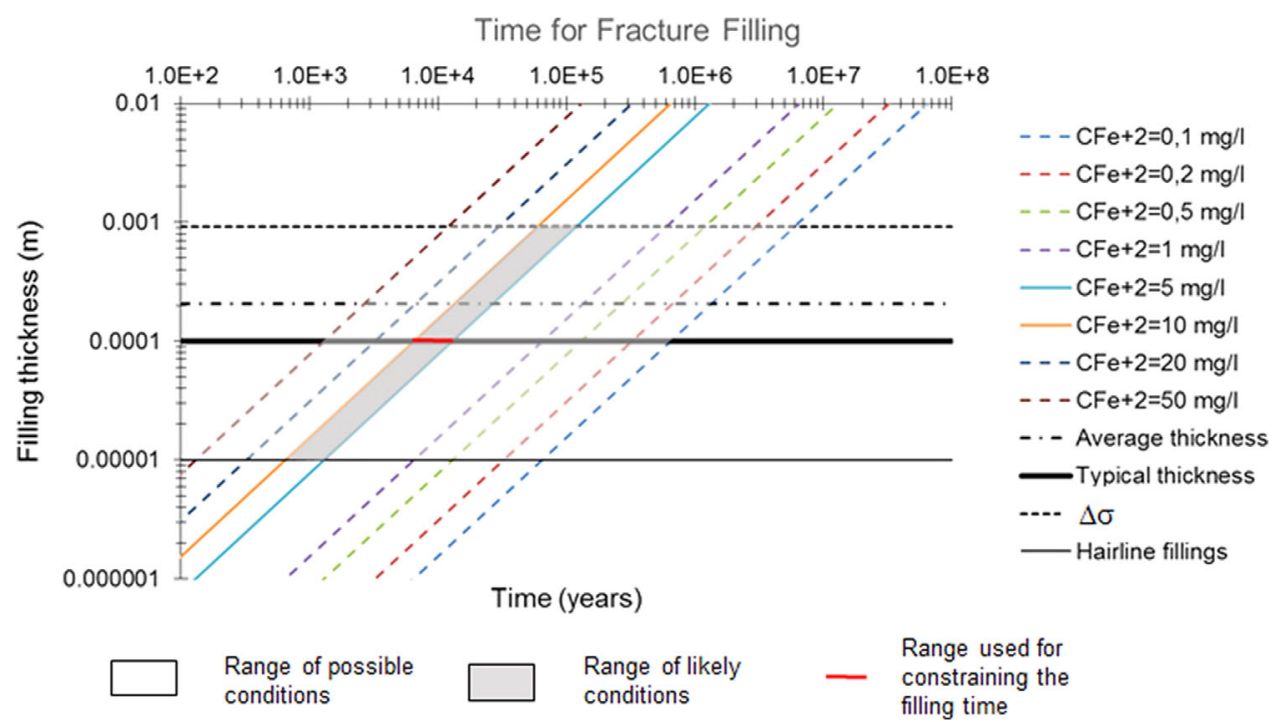

Figure 11. Time required for filling different joint openings with hydroxide mineral under different initial $\mathrm{Fe}^{2+}$ concentrations in the pore water of the matrix. A continuous line indicates the most likely $\mathrm{Fe}^{2+}$ concentrations. The thin horizontal black line represents the joints with hairline opening, which are always completely filled; the thick horizontal black line represents the typical filling thickness observed in joints and faults; the dash dotted line represents the average filling thickness; the thinly dashed line represents the $+\sigma$ of the filling thickness data sample. The dark gray area includes all outcrop observed filling thickness within $\mathrm{Fe}^{2+}$ concentrations that are likely for reducing aquifers Appelo and Postma [2005]. The thick red segment is the range of data used to constrain the length of time for the filling process. 
instantaneous and homogeneous [Sidborn and Neretnieks, 2007] and/or the diffusion of both Fe ${ }^{2+}$ and DO toward a stationary front slightly oscillates in time (Figure 4b) [Ortoleva et al., 1987a, 1987b].

\subsection{Alteration Halo As Indicator for Fluid Flow Timing}

The results of the analytical modeling give us some clues about the time when joints were open to fluid flow. In the following discussion, we consider exposures of the alteration halos at the fracture inlet (Figure 9) and exposures below the fracture inlet (Figure 10). The fractures exposed are on bed layers at a distance of $0.2-0.5 \mathrm{~m}$ from the topographic surface. The soil thickness does not exceed $0.2 \mathrm{~m}$; the halos observed, therefore, were measured down to a depth of 0.3-0.35 $\mathrm{m}$ from the fracture inlet. The two analytical solutions [Sidborn and Neretnieks, 2007; Rajaram and Arshadi, 2016] are similar and give the same timing for fluid flow within the fracture network. The results are sensitive to the choice of $D_{e}$, which in turn is controlled by porosity and tortuosity. The analytical solutions at the fracture inlet indicate that the alteration halo widths observed would form in a period starting 2000-2500 years before present using $D_{e}(\max ), 4000-5500$ years before present using $D_{e}(a v g)$, and 14,000-21,000 years before present using $D_{e}(\min )$ (Figure 9). Also, the development of the front with depth from the inlet indicates a timing for flow starting $2200 \pm 500$ years before present using $D_{e}(\max )$ in the analytical solutions (equations (4) and (9)), $4600 \pm 900$ years before present using $D_{e}(a v g)$, and 16,000 \pm 4000 years before present using $D_{e}(\min )$ (Figure 10). The $2200 \pm 500$ and $4600 \pm 900$ years age determinations from start of fluid flow would make it a recent Holocene phenomenon. On the other hand, the $16,000 \pm 4000$ years age determination from start of fluid flow would set the beginning of the process at the end of the last Würm ice age (Figure 9) [NEEM Community Members, 2013]. The porosity used in the computation of $D_{e}$ has an important effect on the results of this analysis. Given that the optical porosity determination $\left(\begin{array}{ll}n & 0.023\end{array}\right)$ is similar to the lower range of the lab measurement (n 0.02), we think that the age determinations obtained with $D_{e}$ average and $D_{e}$ minimum are the most likely. Combining these two age determinations would set a likely timing for the start of fluid flow at t $10,000 \pm 4000$ years.

In a geologic context, it is more likely that fluid circulation started about 10,000 \pm 4000 years before present at the end of the Würm glacial period and the onset of the Holocene. During the last ice age, in fact, a sea level drop caused increased erosion in the Northern Apennines (Italy) [Ori et al., 1986]. The fast erosion rate could have brought the fractured rocks closer to the topographic surface and allowed percolation of meteoric water through the joint network. The climate was humid and snow-cover persistent, promoting saturation conditions up to the surface. In the last $10,000 \pm 4000$ years, the strong erosion associated with flow through the fracture network (increase in neutral pore pressures) caused extensive mass movements due to bedding-parallel sliding along clay-marl levels interlayered to the fractured MOV sandstone [Regione EmiliaRomagna, 2016].

The dark gray color of the unaltered sandstone suggests that the pore water in the matrix of the MOV Fm experienced reducing conditions ( $c_{\mathrm{Fe}}^{2+}$ between 0.1 and $50 \mathrm{mg} / \mathrm{L}$ [Appelo and Postma, 2005]). The diagram in Figure 11, obtained from equation (11), approximately indicates for how long the joints were open for water circulation and for mass transfer by diffusion. We discuss only the likely concentration of $\mathrm{Fe}^{2+}$ in the pore water of a reducing aquifer $\left(\mathrm{C}_{\mathrm{Fe}}^{2+}\right.$ between 5 and $\left.10 \mathrm{mg} / \mathrm{L}\right)$ and not the extreme values [Appelo and Postma, 2005]. The joints with a filling typically observed in the field $(0.0001 \mathrm{~m})$ require a period of about 6000 10,000 years to fill (Figure 11). This estimate is similar to that obtained with the analytical solutions. Despite the uncertainty in the timing of fluid flow $(10,000 \pm 4000$ years from present time-likely value), we observe that the age of the rock dates back to about 70-75 m.y. ago (Late Campanian-Maastrichtian) and deformation resulting in the structures observed in outcrop started 56 m.y. ago (Late Paleocene) [Cibin et al., 2001]. Fluid flow might have happened at any time in the last $56 \mathrm{Ma}$. Our analysis, however, constrains the timing to the last $10,000 \pm 4000$ years, which we consider a good approximation in a geologic perspective.

Equation (10) and a joint spacing of $0.05-0.1 \mathrm{~m}$, as observed in Figure $7 \mathrm{~b}$, predict that a continuous homogeneous redox front would form after $4600 \pm 900$ years at a depth of $0.3-0.4 \mathrm{~m}$ from the surface. This is what we see in Figure $7 \mathrm{~b}$ and Table 4. Application of equation (10) and a joint spacing of $0.5 \mathrm{~m}$, as observed in the map of Figure 3, shows that a continuous penetration front cannot form at or below the fracture inlet (Table 4). This is what we observed in the outcrop (Figures 1c, 3, and 7b). Fracture mechanics predicts that long fractures are associated with large openings [Pollard and Segall, 1987] and large flow rates [Nelson, 2001], so that more DO diffuses into the matrix along the long fractures rather than the short ones and this 
would be detectable below the fracture inlet. Based on the field data alone and the conditions of the exposure, however, we are not able to confirm this relationship (Figure 6).

Not all faults and none of the veins are associated with alteration halos. This observation indicates that the veins were not open during the period of flow within the joint network, so that they were not conductive to fluids. The presence of the veins, on the other hand, seems to prevent the propagation of the redox fronts (Figures $4 a$ and $5 a$ ) especially where their trace is at low angle from the trace of the joints (Figure 5a). This is due to a different effective diffusion coefficient within the vein-filling material with respect to the porous matrix (Figure 4c).

Sensitivity analysis using equations (3), (4), and (9) showed that, to account for the barrier effect observed in proximity to the veins (Figure $4 \mathrm{a}$ ), the $D_{e}$ in the porous matrix should decrease by $3-5$ orders of magnitude (reduction of alteration halo width from $0.1 \mathrm{~m}$ to $0.0001-0.003 \mathrm{~m}$ in 5000 years; Figure $4 \mathrm{c}$ ). To the best of our knowledge, data on the variation of $D_{e}$ due to rock heterogeneities at the outcrop scale are not reported in the literature. At field scale, Zhou et al. [2007] derived $D_{e}$ for fractured rocks by using tracer tests. Our observations, on the other hand, show that there might be small heterogeneities within a fractured rock mass that cause variations in $D_{e}$ larger than 3-5 orders of magnitudes. Veins may have an important role in controlling diffusion within deformed and mineralized rocks.

\subsection{Implications for Pollutant Transport}

Our field observations showed that all joints and some faults regardless of orientation were conductive to meteoric water flow during the last 10,000 \pm 4000 years. Today, fluid flow and advective transport may still happen through the joints in the outcrop of this study. Pollutants, eventually, would move by diffusion from the fracture network into the porous matrix. In terms of vulnerability to pollutants, aquifers in the MOV Fm experience problems common to all fractured aquifers such as fast transport rates, scarce biodegradation, and difficult assessment of tortuosity and dispersion effects within the fracture network [Krasny and Sharp, 2009; Díaz et al., 2015].

\section{Conclusions}

The excellent outcrop exposure in the Northern Apennines (Italy) described in this paper documents the characteristics of fluid flow and mass transport by diffusion in a fracture network consisting of joints, veins, and faults associated with alteration halos (reactive fronts). This is an opportunity to compare theoretical predictions from analytical models for reaction front propagation in a fracture-matrix system with observations of a real outcrop. We used the outcrop observations to understand the fluid flow and mass transport behavior for each fracture type present in the rock mass and to identify the period during which these processes occurred. We observed alteration halos mostly associated with the joints and in some cases with small offset faults. An important finding is that at shallow depth, all joints, regardless of their orientation are conductive to meteoric water infiltrating from the topographic surface. On the other hand, fractures filled with calcite cement (veins) are not conductive to fluid flow and function as a barrier to diffusion and the development of alteration halos. The effective diffusion coefficient across calcite-filled veins is 3-5 orders of magnitude smaller than in the pristine sandstone.

The fracture network made up by joints with multiple orientations was the most important element for the transport of fluids and mass in the Monte Venere Fm. The characteristics of the alteration halos point out that fluid flow was mostly concentrated in the joint network. The characteristics of the alteration halos also suggest that most of the advective transport occurred in the joint network whereas transport by diffusion occurred from the joint walls into the rock matrix (DO) and from the rock matrix toward the joint opening $\left(\mathrm{Fe}^{+2}\right)$. The analytic modeling and the geometric properties of the alteration halos exposed in outcrop suggest that the joint network was likely open and connected during the last 10,000 \pm 4000 years-a period extending from the end of the last Würmian ice age into Holocene. This age is consistent with a simple diffusion-based joint filling model and with the fast erosion rate occurring in the outcrop area during the Würmian. The fast erosion rate probably allowed meteoric water to reach the fracture network and the start of the diffusion-driven reactive processes observed in the outcrop.

We conclude that analytical modeling is an important tool for the determination of transport and reaction time scales in fractured formations where it is constrained by a robust petrophysical and chemical 
properties data set (porosity, tortuosity, chemical composition of the rock, fluids, alteration products, etc.). The acquisition of such a data set is the most important challenge for this kind of work.

\section{Acknowledgments}

The authors acknowledge funding for fundamental basic research awarded by the University of Bologna. Three anonymous reviewers and Editor Harihar Rajaram have greatly contributed in improving the quality of our manuscript. We thank Enrico Dinelli for interesting discussions on the topic. Supporting data may be obtained from Marco Antonellin (e mail: m.antonellini@unibo.it).

\section{References}

Akagawa, F., H. Yoshida, S. Yogo, and K. Yamomoto (2006), Redox front formation in fractured crystalline rock: An analogue of matrix diffu sion in an oxidizing front along water conducting fractures, Geochem. Explor. Environ. Anal., 6(1), 49 56, doi:10.1144/1467 7873/05 085. Antonellini, M., and P. N. Mollema (2002), Cataclastic faults in the Loiano sandstones; Northern Apennines, Italy, Boll. Soc. Geol. Ital., $121(2), 163178$. Appelo, C. A. J., and D. Postma (2005), Ground Water Geochemistry, Balkema, Amsterdam, The Netherlands.

Argnani, A., D. Fontana, C. Stefani, and G. G. Zuffa (2006), Palaeogeography of the Upper Cretaceous Eocene carbonate turbidites of the Northern Apennines from provenance studies, Geol. Soc. Spec. Publ., 262, 259 275, doi:10.1144/GSL.SP.2006.262.01.16.

Aydin, A. (2000), Fractures, faults, and hydrocarbon entrapment, migration and flow, Mar. Pet. Geol., 17(7), 797 814, doi:10.1016/S0264 $8172(00) 000209$.

Banwart, S. A., E. Gustafsson, and M. Laaksharju (1999), Hydrological and reactive processes during rapid recharge to fracture zones, Appl. Geochem., 14(7), 873 892, doi:10.1016/S0883 2927(99)00029 3.

Binet, S., H. Jomard, T. Lebourg, Y. Guglielmi, E. Tric, C. Bertrand, and J. Mudry (2007), Experimental analysis of groundwater flow through a landslide slip surface using natural and artificial water chemical tracers, Hydrol. Processes, 21(25), 3463 3472, doi:10.1002/hyp.6579.

Binet, S., L. Spadini, C. Bertrand, Y. Guglielmi, J. Mudry, and C. Scavia (2009), Variability of the groundwater sulfate concentration in frac tured rock slopes: A tool to identify active unstable areas, Hydrol. Earth Syst. Sci., 13(12), 23152327.

Bordoni, P., et al. (2007), Cavola experiment site: Geophysical investigations and deployment of a dense seismic array on a landslide, Ann. Geophys., 50(5), 627649.

Bordoni, P., G. di, A. J. Haines, F. Cara, G. Milana, and A. Rovelli (2010), Issues in choosing the references to use for spectral ratios from observations and modeling at Cavola Landslide in Northern Italy, Bull. Seismol. Soc. Am., 100(4), 1578 1613, doi:10.1785/0120090116.

Bronnimann, C. S. (2011), Effect of groundwater on landslide triggering, PhD dissertation, pp. 239, École Polytechnique Federale de Lau sanne, Lausanne, Switzerland.

Brown, J. G., R. L. Bassett, and P. D. Glynn (1998), Analysis and simulation of reactive transport of metal contaminants in ground water in Pinal Creek Basin, Arizona, J. Hydrol., 209(1 4), 225 250, doi:10.1016/S0022 1694(98)00091 2.

Bryant, S. L., and K. E. Thompson (2001), Theory, modeling and experiment in reactive transport in porous media, Curr. Opin. Colloid Inter face Sci., 6(3), 217 222, doi:10.1016/S1359 0294(01)00088 7.

Cervi, F., A. Corsini, A. Ghinoi, F. Ronchetti, and M. Pellegrini (2007), Analisi della predisposizione al manifestarsi di sorgenti in area appen ninica: Un approccio statistic applicato all'area del Monte Modino (Provincia di Modena), Il Geologodell'Emilia Romagna, 7, 2329.

Chen, J. S., and C. W. Liu (2002), Numerical simulation of the evolution of aquifer porosity and species concentrations during reactive trans port, Comput. Geosci., 28(4), 485 499, doi:10.1016/S0098 3004(01)00084 X.

Cibin, U., E. Spadafora, G. G. Zuffa, and A. Castellarin (2001), Continental collision history from arenites of episutural basins in the Northern Apennines, Italy, Bull. Geol. Soc. Am., 113(1), 4 19, doi:10.1130/0016 7606(2001)113 < 0004:CCHFAO>2.0.CO;2.

Cooper, R. S., and D. A. Liberman (1970), Fixed bed adsorption kinetics with pore diffusion control, Ind. Eng. Chem. Fundam., $9(4), 620623$.

Cribbin, L. B., H. F. Winstanley, S. L. Mitchell, A. C. Fowler, and G. C. Sander (2014), Reaction front formation in contaminant plumes, J. Con tam. Hydrol., 171, 12 21, doi:10.1016/j.jconhyd.2014.10.006.

Díaz, G., P. N. Mollema, and M. Antonellini (2015), Fracture patterns and fault development in the pelagic limestones of the Monte Conero anticline (Italy), Ital. J. Geosci., 134(3), 495 512, doi:10.3301/IJG.2014.33.

Dideriksen, K., B. C. Christiansen, C. Frandsen, T. Balic Zunic, S. Mørup, and S. L. S. Stipp (2010), Paleo redox boundaries in fractured granite, Geochim. Cosmochim. Acta, 74(10), 2866 2880, doi:10.1016/j.gca.2010.02.022.

Domenico, P. A., and F. W. Schwartz (1998), Physical and Chemical Hydrogeology, 2nd ed., John Wiley, Chichester, U. K.

Drake, H., E. L. Tullborg, and A. B. MacKenzie (2009), Detecting the near surface redox front in crystalline bedrock using fracture mineral distribution, geochemistry and U series disequilibrium, Appl. Geochem., 24(5), 1023 1039, doi:10.1016/j.apgeochem.2009.03.004.

Eichhubl, P., W. L. Taylor, D. D. Pollard, and A. Aydin (2004), Paleo fluid flow and deformation in the Aztec Sandstone at the Valley of Fire, Nevada Evidence for the coupling of hydrogeological, diagenetic, and tectonic processes, Bull. Geol. Soc. Am., 116(9 10), 1120 1136, doi:10.1130/B25446.1.

Eichhubl, P., P. S. D'Onfro, A. Aydin, J. Waters, and D. K. McCarty (2005), Structure, petrophysics, and diagenesis of shale entrained along a normal fault at Black Diamond Mines, California Implications for fault seal, AAPG Bull., 89(9), 1113 1137, doi:10.1306/04220504099.

Eichhubl, P., N. C. Davatzes, and S. P. Becker (2009), Structural and diagenetic control of fluid migration and cementation along the Moab fault, Utah, AAPG Bull., 93(5), 653 681, doi:10.1306/02180908080.

Esposito, S. J., and N. R. Thomson (1999), Two phase flow and transport in a single fracture porous medium system, J. Contam. Hydrol., 37(3 4), 319 341, doi:10.1016/S0169 7722(98)00169 7.

Galeandro, A., A. Doglioni, V. Simeone, and J. Simünek (2014), Analysis of infiltration processes into fractured and swelling soils as trigger ing factors of landslides, Environ. Earth Sci., $71(6), 2911$ 2923, doi:10.1007/s12665 01326667.

Gasperi, G., G. Bettelli, F. Panini, and M. Pizziolo (2005), Note illustrative della carta geologica d'Italia scala 1:50000, foglio 219, Sassuolo, 197 pp., Regione Emilia Romagna, Bologna, Italy.

Greer, K. D., J. W. Molson, J. F. Barker, N. R. Thomson, and C. R. Donaldson (2010), High pressure injection of dissolved oxygen for hydrocar bon remediation in a fractured dolostone aquifer, J. Contam. Hydrol., 118(1 2), 13 26, doi:10.1016/j.jconhyd.2010.07.007.

Grisak, G. E., and J. F. Pickens (1980), Solute transport through fractured media: 1. The effect of matrix diffusion, Water Resour. Res., 16(4), 719 730, doi:10.1029/WR016i004p00719.

Grisak, G. E., J. F. Pickens, and J. A. Cherry (1980), Solute transport through fractured media: 2. Column study of fractured till, Water Resour. Res., 16(4), 731 739, doi:10.1029/WR016i004p00731.

Hartley, L., S. Joyce, H. Woollard, N. Marsic, M. Sidborn, B. Gylling, I. Puigdomenech, and L. Koskinen (2015), Coupled groundwater flow and reactive transport simulations of the evolution of groundwater chemistry for a deep geologic repository in shield rocks, in IAH CNC, Waterloo, Ont., Canada.

Hatiboglu, C. U., and T. Babadagli (2010), Experimental and visual analysis of diffusive mass transfer between matrix and fracture under static conditions, J. Pet. Sci. Eng., 74(1 2 2), 31 40, doi:10.1016/j.petrol.2010.08.004.

Hölttä, P., A. Poteri, M. Siitari Kauppi, and N. Huittinen (2008), Retardation of mobile radionuclides in granitic rock fractures by matrix diffu sion, Phys. Chem. Earth, 33(14 16), 983 990, doi:10.1016/j.pce.2008.05.010. 
Houseworth, J. E. (2006), An analytical model for solute transport in unsaturated flow through a single fracture and porous rock matrix, Water Resour. Res., 42, W01416, doi:10.1029/2004WR003770.

Houseworth, J. E., D. Asahina, and J. T. Birkholzer (2013), An analytical model for solute transport through a water saturated single fracture and permeable rock matrix, Water Resour. Res., 49, 6317 6338, doi:10.1002/wrcr.20497.

Huang, J., and M. N. Goltz (2015), Semi analytical solutions for transport in aquifer and fractured clay matrix system, Water Resour. Res., 51, 7218 7237, doi:10.1002/2014WR016073.

Ingebritsen, S. E., and W. E. Sanford (2006), Groundwater in Geologic Processes, 2nd ed., Cambridge University Press, Cambridge, U. K.

Jomard, H., T. Lebourg, S. Binet, E. Tric, and M. Hernandez (2007), Characterization of an internal slope movement structure by hydrogeo physical surveying, Terra Nova, 19(1), 48 57, doi:10.1111/j.1365 3121.2006.00712.x.

Krasny, J., and J. M. Sharp (2009), Groundwater in Fractured Rocks, IAH Sel. Pap. Ser., vol. 9, Taylor and Francis, London.

Kresic, N. (2006), Hydrogeology and Groundwater Modeling, 2nd ed., CRC Press, Boca Raton, Fla.

Lee, H. B., and B. W. Kim (2015), Characterization of hydraulically active fractures in a fractured granite aquifer, Water SA, 41(1), 139 148, doi:10.4314/wsa.v41i1.17.

Leuratti, E., C. C. Lucente, E. Medda, V. Manzi, A. Corsini, G. Tosatti, F. Ronchetti, and M. Guerra (2007), Primi interventi di consolidamento sulle frane dei Boschi di Valoria, di Tolara e Lezza Nuova (Val Dolo e Val Dragone, Appennino modenese), G. Geol. Appl., 7, 1730.

Lever, D. A., and M. H. Bradbury (1985), Rock matrix diffusion and its implications for radionuclide migration, Mineral. Mag., $49(2), 245254$. Liu, Q. Q., and J. C. Li (2015), Effects of water seepage on the stability of soil slopes, Proc. IUTAM, 17, 29 39, doi:10.1016/j.piutam.2015.06.006.

MacQuarrie, K. T. B., and K. U. Mayer (2005), Reactive transport modeling in fractured rock: A state of the science review, Earth Sci. Rev., 72(3 4), 189 227, doi:10.1016/j.earscirev.2005.07.003.

MacQuarrie, K. T. B., K. U. Mayer, B. Jin, and S. M. Spiessl (2010), The importance of conceptual models in the reactive transport simulation of oxygen ingress in sparsely fractured crystalline rock, J. Contam. Hydrol., 112(1 4), 64 76, doi:10.1016/j.jconhyd.2009.10.007.

Marshall, L. J., and N. H. S. Oliver (2008), Constraints on hydrothermal fluid pathways within Mary Kathleen Group stratigraphy of the Clon curry iron oxide copper gold District, Australia, Precambrian Res., 163(1 2), 151 158, doi:10.1016/j.precamres.2007.08.016.

Mazurek, M., W. R. Alexander, and A. B. Mackenzie (1996), Contaminant retardation in fractured shales: Matrix diffusion and redox front entrapment, J. Contam. Hydrol., 21(1 4), 71 84, doi:10.1016/0169 7722(95)00034 8.

Meisina, C. (2006), Characterization of weathered clayey soils responsible for shallow landslides, Nat. Hazards Earth Syst. Sci., $6(5), 825838$.

Miller, W., R. Alexander, N. Chapman, I. McKinley, and J. Smellie (1994), Natural Analogue Studies in the Geological Disposal of Radioactive Wastes, Stud. Environ. Sci., vol. 57, Elsevier, Amsterdam.

Molinero, J., and J. Samper (2006), Large scale modeling of reactive solute transport in fracture zones of granitic bedrocks, J. Contam. Hydrol., 82(3 4), 293 318, doi:10.1016/j.jconhyd.2005.10.008.

Mutch, J., J. I. Scott, and D. J. Wilson (1993), Cleanup of fractured rock aquifers: Implications of matrix diffusion, Environ. Monit. Assess., 24(1), 45 70, doi:10.1007/BF00568799.

NEEM Community Members (2013), Eemian interglacial reconstructed from a Greenland folded ice core, Nature, 493(7433), 489 494, doi: 10.1038 /nature11789.

Nelson, R. A. (2001), Geologic Analysis of nNturally Fractured Reservoirs, Elsevier, Oxford, U. K.

Neretnieks, I. (1986), Some uses for natural analogues in assessing the function of a HLW repository, Chem. Geol., $55(3$ 4), 175 188, doi: 10.1016/0009 2541(86)90022 7.

Ori, G. G., M. Roveri, and F. Vannoni (1986), Plio Pleistocene sedimentation in the Apenninic Adriatic foredeep (central Adriatic Sea, Italy), in Foreland Basins, pp. 183 198, edited by P. A. Allen and P. Homewood, Blackwell, Oxford, U. K.

Ortoleva, P., G. Auchmuty, J. Chadam, J. Hettmer, E. Merino, C. H. Moore, and E. Ripley (1986), Redox front propagation and banding modal ities, Physica D, 19(3), 334 354, doi:10.1016/0167 2789(86)90063 1.

Ortoleva, P., E. Merino, C. Moore, and J. Chadam (1987a), Geochemical self organization I; reaction transport feedbacks and modeling approach, Am. J. Sci., 287, 9791007.

Ortoleva, P., E. Merino, J. Chadam, and A. Sen (1987b), Geochemical self organization II; the reactive infiltration instability, Am. J. Sci., 287, 10081040.

Park, J. B., Y. Hwang, and K. J. Lee (2001), Analytic solutions of radionuclide transport with the limited diffusion from the fracture into a porous rock matrix, Ann. Nucl. Energy, 28(10), 993 1011, doi:10.1016/S0306 4549(00)001031.

Pollard, D. D., and P. Segall (1987), Theoretical displacements and stresses near fractures in rock: With applications to faults, joints, veins, dikes, and solution surfaces, in Fracture Mechanics of Rock, edited by B. K. Atkinson, pp. 277 349, Academic, London.

Priest, S. D., and J. A. Hudson (1976), Discontinuity spacing in rock, Int. J. Rock Mech. Min. Sci. Geomech. Abstr., 13,135148

Priest, S. D., and J. A. Hudson (1981), Estimation of discontinuity spacing and trace length using scanline surveys, Int. J. Rock Mech. Min. Sci. Geomech. Abstr., 18(3), 183 197, doi:10.1016/0148 9062(81)90973 6.

Rajaram, H., and M. Arshadi (2016), A similarity solution for reaction front propagation in a fracture matrix system, Philos. Trans. R. Soc. A, 374, doi:10.1098/rsta.2015.0424.

Regione Emilia Romagna (2016), General Characteristics of Landslides, Bologna, Italy. [Available at http://ambiente.regione.emilia romagna. it/geologia/temi/dissesto idrogeologico/le caratteristiche dei fenomeni franosi in emilia romagna.]

Reimus, P. W., and T. J. Callahan (2007), Matrix diffusion rates in fractured volcanic rocks at the Nevada Test Site: Evidence for a dominant influence of effective fracture apertures, Water Resour. Res., 43, W07421, doi:10.1029/2006WR005746.

Ronchetti, F., L. Borgatti, F. Cervi, L. Piccinini, and A. Corsini (2008), Modellazione numerica dei meccanismi di riattivazione di grandi frane per scivolamento di terra: I'esempio della frana di Tolara, Appennino settentrionale, G. Geol. Appl., 8, 217232.

Rubin, H., D. Dveyrin, J. Birkhölzer, and G. Rouvé (1997), Advection and dispersion of contaminant in a permeable medium embedding fractures in which advection velocity is comparatively slow, J. Hydrol., 199(1 2), 135 162, doi:10.1016/S0022 1694(96)03258 1.

Sausse, J., E. Jacquot, B. Fritz, J. Leroy, and M. Lespinasse (2001), Evolution of crack permeability during fluid rock interaction. Example of the Brézouard granite (Vosges, France), Tectonophysics, 336(1 4), 199 214, doi:10.1016/S0040 1951(01)00102 0.

Schultz, R. A., and H. Fossen (2008), Terminology for structural discontinuities, AAPG Bull., 92(7), 853 867, doi:10.1306/02200807065.

Shapiro, A. M. (2001), Effective matrix diffusion in kilometer scale transport in fractured crystalline rock, Water Resour. Res., $37(3), 507522$, doi:10.1029/2000WR900301.

Sidborn, M., and I. Neretnieks (2007), Long term redox evolution in granitic rocks: Modelling the redox front propagation in the rock matrix, Appl. Geochem., 22(11), 2381 2396, doi:10.1016/j.apgeochem.2007.05.007.

Sidborn, M., and I. Neretnieks (2008), Long term oxygen depletion from infiltrating groundwaters: Model development and application to intra glaciation and glaciation conditions, J. Contam. Hydrol., 100(1 2 2), 72 89, doi:10.1016/j.jconhyd.2008.05.010.

Smellie, J. A. T., and F. Karlsson (1999), The use of natural analogues to assess radionuclide transport, Eng. Geol., 59(3 4), 193220. 
Spiessl, S. M., H. Prommer, T. Licha, M. Sauter, and C. Zheng (2007), A process based reactive hybrid transport model for coupled discrete conduit continuum systems, J. Hydrol., 347(1 2 2), 23 34, doi:10.1016/j.jhydrol.2007.08.026.

Steefel, C. I., D. J. DePaolo, and P. C. Lichtner (2005), Reactive transport modeling: An essential tool and a new research approach for the Earth sciences, Earth Planet. Sci. Lett., 240(3 4), 539 558, doi:10.1016/j.epsl.2005.09.017.

Sudicky, E. A., and E. O. Frind (1982), Contaminant transport in fractured porous media: Analytical solutions for a system of parallel frac tures, Water Resour. Res., 18(6), 1634 1642, doi:10.1029/WR018i006p01634.

Szalai, S., K. Szokoli, and M. Metwaly (2014), Delineation of landslide endangered areas and mapping their fracture systems by the pressure probe method, Landslides, 11(5), 923 932, doi:10.1007/s10346 01405096.

Tang, D. H., E. O. Frind, and E. A. Sudicky (1981), Contaminant transport in fractured porous media: Analytical solution for a single fracture, Water Resour. Res., 17(3), 555 564, doi:10.1029/WR017i003p00555.

Trivedi, J. J., and T. Babadagli (2009), Experimental and numerical modeling of the mass transfer between rock matrix and fracture, Chem. Eng. J., 146(2), 194 204, doi:10.1016/j.cej.2008.05.032.

Tsang, C. F., I. Neretnieks, and Y. Tsang (2015), Hydrologic issues associated with nuclear waste repositories, Water Resour. Res., 51, 6923 6972, doi:10.1002/2015WR017641.

Vujevic, K., and T. Graf (2015), Combined inter and intra fracture free convection in fracture networks embedded in a low permeability matrix, Adv. Water Resour., 84, 52 63, doi:10.1016/j.advwatres.2015.07.014.

Watanabe, N., and O. Kolditz (2015), Numerical stability analysis of two dimensional solute transport along a discrete fracture in a porous rock matrix, Water Resour. Res., 51, 5855 5868, doi:10.1002/2015WR017164.

Willmann, M., G. W. Lanyon, P. Marschall, and W. Kinzelbach (2013), A new stochastic particle tracking approach for fractured sedimentary formations, Water Resour. Res., 49, 352 359, doi:10.1029/2012WR012191.

Wörman, A., S. Xu, and B. Dverstorp (2003), Kinematic analysis of solute mass flows in rock fractures with spatially random parameters, J. Contam. Hydrol., 60(3 4), 163 191, doi:10.1016/S0169 7722(02)00088 8.

Wu, Y. S., M. Ye, and E. A. Sudicky (2010), Fracture flow enhanced matrix diffusion in solute transport through fractured porous media, Transp. Porous Media, 81(1), 21 34, doi:10.1007/s11242009 93834.

Yang, C., J. Samper, and J. Molinero (2008), Inverse microbial and geochemical reactive transport models in porous media, Phys. Chem. Earth, 33(14 16), 1026 1034, doi:10.1016/j.pce.2008.05.016.

Yoshida, H., K. Yamamoto, S. Yogo, and Y. Murakami (2006), An analogue of matrix diffusion enhanced by biogenic redox reaction in frac tured sedimentary rock, J. Geochem. Explor., 90(1 2$), 134$ 142, doi:10.1109/MEMSYS.2006.1627754.

Zhou, Q., H. H. Liu, F. J. Molz, Y. Zhang, and G. S. Bodvarsson (2007), Field scale effective matrix diffusion coefficient for fractured rock: Results from literature survey, J. Contam. Hydrol., 93(1 4), 161 187, doi:10.1016/j.jconhyd.2007.02.002. 